\title{
Sources and characteristics of summertime organic aerosol in the Colorado Front Range: perspective from measurements and WRF-Chem modeling
}

\author{
Roya Bahreini ${ }^{1,2}$, Ravan Ahmadov ${ }^{3,4}$, Stu A. McKeen ${ }^{3,4}$, Kennedy T. Vu ${ }^{2}$, Justin H. Dingle ${ }^{2}$, Eric C. Apel ${ }^{5}$, Donald \\ R. Blake ${ }^{6}$, Nicola Blake ${ }^{6}$, Teresa L. Campos ${ }^{5}$, Chris Cantrell ${ }^{7}$, Frank Flocke ${ }^{5}$, Alan Fried ${ }^{8}$, Jessica B. Gilman ${ }^{3}$, Alan \\ J. Hills ${ }^{5}$, Rebecca S. Hornbrook ${ }^{5}$, Greg Huey ${ }^{9}$, Lisa Kaser ${ }^{5}$, Brian M. Lerner ${ }^{3,4, a}$, Roy L. Mauldin ${ }^{7}$, \\ Simone Meinardi ${ }^{6}$, Denise D. Montzka ${ }^{5}$, Dirk Richter ${ }^{8}$, Jason R. Schroeder ${ }^{6, b}$, Meghan Stell ${ }^{5}$, David Tanner ${ }^{9}$, \\ James Walega $^{8}$, Peter Weibring ${ }^{8}$, and Andrew Weinheimer ${ }^{5}$ \\ ${ }^{1}$ Department of Environmental Sciences, University of California, Riverside, CA 92521, USA \\ ${ }^{2}$ Environmental Toxicology Graduate Program, University of California, Riverside, CA 92521, USA \\ ${ }^{3}$ Earth System Research Laboratory, National Oceanic and Atmospheric Administration, Boulder, CO 80305, USA \\ ${ }^{4}$ Cooperative Institute for Research in Environmental Sciences, University of Colorado, Boulder, CO 80301, USA \\ ${ }^{5}$ Atmospheric Chemistry Observations and Modeling Laboratory, National Center for Atmospheric Research, Boulder, \\ CO 80301, USA \\ ${ }^{6}$ Department of Chemistry, University of California, Irvine, CA 92697, USA \\ ${ }^{7}$ Department of Atmospheric and Oceanic Sciences, University of Colorado, Boulder, CO 80303, USA \\ ${ }^{8}$ Institute for Arctic and Alpine Research, University of Colorado, Boulder, CO 80303, USA \\ ${ }^{9}$ Department of Earth and Atmospheric Sciences, Georgia Institute of Technology, Atlanta, GA 30033, USA \\ anow at: Aerodyne Research, Inc., Billerica, MA 01821, USA \\ b now at: NASA Langley Research Center, Newport News, VA 23666, USA
}

Correspondence: Roya Bahreini (roya.bahreini@ucr.edu)

Received: 20 January 2018 - Discussion started: 24 January 2018

Revised: 3 May 2018 - Accepted: 23 May 2018 - Published: 14 June 2018

\begin{abstract}
The evolution of organic aerosols (OAs) and their precursors in the boundary layer (BL) of the Colorado Front Range during the Front Range Air Pollution and Photochemistry Éxperiment (FRAPPÉ, July-August 2014) was analyzed by in situ measurements and chemical transport modeling. Measurements indicated significant production of secondary OA (SOA), with enhancement ratio of OA with respect to carbon monoxide $(\mathrm{CO})$ reaching $0.085 \pm$ $0.003 \mu \mathrm{g} \mathrm{m}^{-3} \mathrm{ppbv}^{-1}$. At background mixing ratios of $\mathrm{CO}$, up to $\sim 1.8 \mu \mathrm{g} \mathrm{m}^{-3}$ background OA was observed, suggesting significant non-combustion contribution to $\mathrm{OA}$ in the Front Range. The mean concentration of OA in plumes with a high influence of oil and natural gas $(\mathrm{O} \& \mathrm{G})$ emissions was $\sim 40 \%$ higher than in urban-influenced plumes. Positive matrix factorization (PMF) confirmed a dominant contribution of secondary, oxygenated OA (OOA) in the boundary layer instead of fresh, hydrocarbon-like OA (HOA). Combinations
\end{abstract}

of primary OA (POA) volatility assumptions, aging of semivolatile species, and different emission estimates from the O\&G sector were used in the Weather Research and Forecasting model coupled with Chemistry (WRF-Chem) simulation scenarios. The assumption of semi-volatile POA resulted in greater than a factor of 10 lower POA concentrations compared to PMF-resolved HOA. Including top-down modified O\& $\mathrm{G}$ emissions resulted in substantially better agreements in modeled ethane, toluene, hydroxyl radical, and ozone compared to measurements in the high-O\&G-influenced plumes. By including emissions from the $\mathrm{O} \& \mathrm{G}$ sector using the topdown approach, it was estimated that the O\&G sector contributed to $<5 \%$ of total OA, but up to $38 \%$ of anthropogenic SOA (aSOA) in the region. The best agreement between the measured and simulated median OA was achieved by limiting the extent of biogenic hydrocarbon aging and consequently biogenic SOA (bSOA) production. Despite a 
lower production of bSOA in this scenario, contribution of bSOA to total SOA remained high at 40-54\%. Future studies aiming at a better emissions characterization of POA and intermediate-volatility organic compounds (IVOCs) from the $\mathrm{O} \& \mathrm{G}$ sector are valuable.

\section{Introduction}

Secondary organic aerosol (SOA) particles are formed from condensation of relatively low vapor pressure species in the atmosphere, generated through oxidation of volatile, semi-volatile, or intermediate-volatility organic compounds (VOCs, SVOCs, or IVOCs, respectively). Since both biogenic and anthropogenic sources contribute to SOA precursors (Hallquist et al., 2009), SOA particles are ubiquitous in the atmosphere and contribute to a large fraction of the submicron non-refractory aerosol mass globally (Zhang et al., 2007). Similar to other aerosol particles, SOA particles deteriorate air quality and visibility and impact the climate directly through absorption and scattering of radiation and indirectly through interactions with clouds (Monks et al., 2009). Despite recent advances in the measurement and modeling aspects of SOAs and their precursors (e.g., Donahue et al., 2006; Ervens and Volkamer, 2010; Hodzic et al., 2010a; de Gouw et al., 2011; Hodzic and Jimenez, 2011; Shrivastava et al., 2011; Ahmadov et al., 2012; Isaacman et al., 2012; Yatavelli et al., 2012; Ehn et al., 2014; Ensberg et al., 2014; Fast et al., 2014; Lopez-Hilfiker et al., 2014; Williams et al., 2014), the full extent of SOA sources, formation processes, and therefore their impact on air quality, human health, and climate are not fully understood.

In recent decades, stricter regulations by the U.S. Environmental Protection Agency and state agencies have resulted in lower emissions of black carbon, hydrocarbons (including air toxics), and nitrogen oxides in many urban environments (e.g., Parrish et al., 2002; Peischl et al., 2010; Sather and Cavender, 2012; Warneke et al., 2012; Zhou et al., 2014; Kirchstetter et al., 2017) while in other areas, both populated and remote, expansion or emergence of new oil and natural gas $(\mathrm{O} \& \mathrm{G})$ exploration and production activities has led to higher emissions of air toxics, methane, and non-methane hydrocarbons, e.g., $\mathrm{C}_{2}-\mathrm{C}_{8}$ and larger alkanes, benzene, and larger aromatic species (e.g., Petron et al., 2012; Gilman et al., 2013; Adgate et al., 2014; Helmig et al., 2014; Pekney et al., 2014; Warneke et al., 2014; Field et al., 2015; Koss et al., 2015; Rutter et al., 2015; Swarthout et al., 2015; Helmig et al., 2016; Prenni et al., 2016; Abeleira et al., 2017; Koss et al., 2017). The impact of higher emissions of such hydrocarbons from oil and gas fields of Utah and Wyoming on wintertime ozone has been assessed through recent measurement and modeling studies (Carter and Seinfeld, 2012; Edwards et al., 2014; Rappenglück et al., 2014; Ahmadov et al., 2015).
The Wattenberg Field, located in the Denver-Julesburg basin (DJB) in the Colorado Front Range and NE of Denver, is the largest oil- and natural-gas-producing field in the state of Colorado and is one of the 20 largest O\&G fields in the United States (RockyMountainEnergyForum 2015). Gas composition in this field is liquid-rich (containing more than $3.8 \mathrm{e}-4 \mathrm{~m}^{3}$ of condensable hydrocarbons per $28 \mathrm{~m}^{3}$ of extracted gas) (Britannica 1998), making Colorado among the top five US states with high yields of wet-gas production (USEDC, 2015). Since 2007, several studies in the Front Range have been carried out in an effort to characterize emissions of methane and light alkanes (up to $\mathrm{C}_{8}$ ) and aromatic species, including benzene, toluene, $\mathrm{C}_{8}$ - and $\mathrm{C}_{9}$ - aromatics from the $O \& G$ activities in the Front Range and their atmospheric impacts in the region (Petron et al., 2012, 2014; Gilman et al., 2013; Swarthout et al., 2013; Abeleira et al., 2017). In the measurement study by Gilman et al. (2013), conducted during February-March 2011 at a site SW of the Wattenberg Field, O\&G emissions contributed to $70 \%$ and $20-30 \%$ of emissions of light alkanes and aromatic species, respectively. Additionally, a high fraction of $\mathrm{OH}$ reactivity $(55 \pm 18 \%)$ was attributed to the light alkanes emitted from the O\&G activities in the Wattenberg Field, highlighting the significance of these emissions as ozone precursors. In summer 2015, morning $\mathrm{OH}$ reactivity was dominated by $\mathrm{O} \& \mathrm{G}$ VOC emissions while in the afternoon isoprene contributed to a higher $\mathrm{OH}$ reactivity (Abeleira et al., 2017). Box model simulations corresponding to observations made at Erie, $\mathrm{CO}$ (southwest corner of the Wattenberg Field), in summer 2012 and 2014 estimated $\sim 80 \%$ of gaseous organic carbon had originated from $\mathrm{O} \& \mathrm{G}$ alkane emissions while contribution of these species to local ozone production was estimated to be $<20 \%$ (McDuffie et al., 2016). On the high-ozone days, O\&G emissions have been estimated to contribute to 30$40 \%$ of ozone in the northern Colorado Front Range - Denver metro area, based on data synthesized from airborne measurements in the Front Range during summer 2014 (Pfister et al., 2017). Despite these recent studies, the contribution of $O \& G$ emissions to summertime organic aerosol (OA) in the region has not been explored before.

During July-August 2014, the Colorado Department of Public Health and Environment (CDPHE), National Science Foundation (NSF), and National Aeronautics and Space Administration (NASA) cosponsored multiplatform field projects in the Colorado Front Range to characterize emissions, processing, and transport of various pollutants in the region. Here, analyses of the airborne data obtained from the NSF/CDPHE-sponsored Front Range Air Pollution and Photochemistry Éxperiment (FRAPPÉ) project, investigating emissions of hydrocarbons, their impact on SOA formation, and OA chemical characterization through positive matrix factorization (PMF), are presented. A regional chemical transport model, the Weather Research and Forecasting model coupled with Chemistry (WRF-Chem), is used with volatility basis set parameterization and sensitivity runs to 
examine effects of primary OA (POA) volatility, biogenic SOA aging schemes, and updated emissions of hydrocarbons from the O\&G sector on SOA formation in the Front Range.

\section{Methods}

\subsection{Measurements}

In situ measurements were made aboard the NSF/NCAR C130 aircraft during 26 July-18 August 2014. The mountainous terrain of the Front Range leads to terrain-induced air mass flow patterns in the region. Typically, during the day, the thermally driven easterly flow transports pollutants towards and up the foothills while at night the flow reverses. During 27-28 July, the region was also under the influence of a mesoscale cyclonic flow, leading to counterclockwise movement of air masses and transfer of pollutants from the northern latitudes towards the Denver metro area ( $\mathrm{Vu}$ et al., 2016). To limit the current analysis to air masses influenced by emissions in the boundary layer (BL) of the Front Range, analyses from samples collected over the Denver metropolitan area and the eastern plains were limited to those at altitudes typically below $1000 \mathrm{~m}$ above ground level (a.g.l.); over the foothills and the continental divide, air masses under the influence of easterly winds sampled at altitudes up to $2500 \mathrm{~m}$ a.g.l. were also considered. Additionally, recirculated air masses, occasionally observed at altitudes up to $1800 \mathrm{~m}$ a.g.l. over the metropolitan area, were also included in this analysis. Overall, $91 \%$ of the data presented here are from altitudes lower than $1000 \mathrm{~m}$ a.g.l., and the contribution of recirculated air masses to the data was minor $(<4 \%)$. Average temperature in the plumes presented in this work was $20.7 \pm 5.8^{\circ} \mathrm{C}$. The influence of different emission sources on sampled air masses was determined based on the measured trace gases as further explained in Sect. 2.2.

Non-refractory submicron aerosol composition, including organic aerosol, was measured with $15 \mathrm{~s}$ frequency using a compact version (mAMS) of the Aerodyne aerosol mass spectrometer equipped with a compact time-of-flight (ToF) detector. Except for the shorter particle time-of-flight chamber and a different pumping system, principles of operation of the mAMS are similar to the full-size AMS instruments, described previously (Jayne et al., 2000; Drewnick et al., 2005; Canagaratna et al., 2007). The mAMS sampled ambient air through a forward-facing, diffusion-type NCAR High-performance Instrumented Airborne Platform for Environmental Research (HIAPER) modular inlet (HIMIL), mounted under the aircraft, and a pressure-controlled inlet (Bahreini et al., 2008; Dingle et al., 2016; Vu et al., 2016). Residence time in the inlet was estimated to be $\sim 0.5 \mathrm{~s}$. Sensitivity calibrations of the instrument were carried out routinely during the project. Variability in the individual calibrations was observed to be less than $10 \%$ and thus an average calibration value was applied to the data obtained from all flights (Vu et al., 2016). Composition-dependent collection efficiency was applied to all the data (Middlebrook et al., 2012a). The estimated uncertainty in the mass concentration of OA was $\sim 30 \%$ (Bahreini et al., 2009) and the detection limit was $\sim 0.4 \mu \mathrm{g} \mathrm{m}^{-3}$ (15 s interval measurements).

The auxiliary gas-phase data used in this analysis are carbon monoxide (CO) by vacuum UV resonance fluorescence (Gerbig et al., 1999); nitric oxide (NO) and nitrogen dioxide $\left(\mathrm{NO}_{2}\right)$ by chemiluminescence (Ridley et al., 2004); ethane $\left(\mathrm{C}_{2} \mathrm{H}_{6}\right)$ by infrared spectrometry (Richter et al., 2015); aromatic and biogenic species by online proton-transfer-reaction mass spectrometry (Lindinger et al., 1998; de Gouw and Warneke, 2007); hydrogen cyanide (HCN); $i$-pentane and $n$ pentane by online cryogenic gas chromatography-mass spectrometry (GC-MS) (Apel et al., 2015); methylcyclohexane and $n$-octane by offline analysis of whole air canister samples (WAS) by GC-MS (Colman et al., 2001); nitric acid $\left(\mathrm{HNO}_{3}\right)$ by chemical ionization mass spectrometry (CIMS) using $\mathrm{SF}_{6}^{-}$as the reagent ion (Huey et al., 1998); peroxyacyl nitrates (PAN and PPN) by I ${ }^{-}$CIMS (Zheng et al., 2011); alkyl nitrates by thermal dissociation laser-induced fluorescence (Day et al., 2002); and hydroxyl (OH), hydroperoxy $\left(\mathrm{HO}_{2}\right)$, and alkyl peroxy $\left(\mathrm{RO}_{2}\right)$ radicals by CIMS (Mauldin et al., 1998; Hornbrook et al., 2011; Ren et al., 2012). $\mathrm{NO}_{y}$ was calculated by summing up the individually measured nitrogen oxide species, namely $\mathrm{NO}, \mathrm{NO}_{2}, \mathrm{HNO}_{3}$, particulate nitrate, PAN, PPN, and alkyl nitrates.

\subsection{Source characterization}

To quantify the contribution of different types of OA factors to total OA, positive matrix factorization was applied to the measured OA spectra during 26 July-11 August. PMF is a multivariate factor analysis method by which input data are categorized into constant profile factors (i.e., factor mass spectra) with varying, positive contributions across time (i.e., factor time series) while minimizing the residual matrix considering the errors associated with each sample (Paatero and Tapper, 1994; Paatero, 1997). The input mass spectra and error matrix of $\mathrm{OA}$ were generated by the $\mathrm{ToF}$ analysis toolkit (v. 159) and used in the PMF Evaluation Toolkit (v. 2.08D). Down-weighting of uncertain and weak fragments with a signal-to-noise ratio of $0.2-2$ and fragments related to $\mathrm{CO}_{2}^{+}$ (i.e., $m / z 16,17,18,28$, and 44) was carried out following the procedures outlined in previous studies (Ulbrich et al., 2009; Ng et al., 2010; Zhang et al., 2011). A total of 100 bootstrap iterations with the ideal number of factors (two, as discussed further in Sect. 3.1) were also carried out to determine the robustness of the resolved factors.

To compare OA production in plumes with an influence of pure urban-related vs. high-O\&G-related emissions, two air mass categories were defined using the auxiliary gas-phase data of $\mathrm{CO}$ and $\mathrm{C}_{2} \mathrm{H}_{6}$ as tracers for urban and $\mathrm{O} \& \mathrm{G}$ emissions, respectively. Urban-influenced air masses were defined as air masses where $\mathrm{CO}$ enhancement over 
Table 1. Settings and parameterizations used for the WRF-Chem simulations.

\begin{tabular}{ll}
\hline Category & Selected options and parameters \\
\hline Land surface & Noah land surface model \\
PBL scheme & Mellor-Yamada-Nakanishi-Niino \\
Microphysics & WRF Single-moment, 5 class scheme \\
Cumulus & Grell-Freitas scheme (12 km domain only) \\
Short- and longwave radiation & RRTMG short- and longwave \\
Gas chemistry & RACM ESRL \\
Aerosol & MADE, VBS-based SOA parameterization \\
Photolysis & Madronich \\
Anthropogenic emissions & NEI 2011v1 \\
Biogenic emissions & BEIS 3.14 \\
\hline
\end{tabular}

the background ( $105 \mathrm{ppbv}$, defined by the mode in the frequency distribution of $\mathrm{CO}$ in the Front Range boundary layer) was observed while $\mathrm{C}_{2} \mathrm{H}_{6} / \mathrm{CO}<20 \mathrm{pptv}_{\text {ppbv }}{ }^{-1}$ (Warneke et al., 2007; Borbon et al., 2013). Plumes with a high influence of $\mathrm{O} \& \mathrm{G}$ emissions were defined by $\mathrm{C}_{2} \mathrm{H}_{6} / \mathrm{CO}>80 \mathrm{pptv} \mathrm{ppbv}^{-1}$ and $\mathrm{C}_{2} \mathrm{H}_{6}$ mixing ratios greater than $10 \mathrm{ppbv}$ (Warneke et al., 2007; Borbon et al., 2013). Data from 11 to 12 August, when influence from regional biomass burning emissions resulted in higher HCN background values (540 vs. $300 \mathrm{pptv}$ ), were eliminated from analysis of the ambient measurements, although the PMF input matrix included data from 11 August.

\subsubsection{WRF-Chem modeling}

The Weather Research and Forecasting model coupled with Chemistry (WRF-Chem) (https://ruc.noaa.gov/wrf/ wrf-chem/, last access: 14 January 2018) is an online meteorology-chemistry model, which is widely used in air quality and atmospheric chemistry applications (Grell et al., 2005; Powers et al., 2017). Table 1 lists the main configurations and parameterizations used to run WRF-Chem. The model includes multiple gas and aerosol chemistry parameterizations with varying levels of complexity, photolysis, and removal (dry and wet) mechanisms. The model also contains the state-of-the-art SOA schemes based on a volatility basis set approach. In this study, we used an SOA scheme mostly based on the RACM_SOA_VBS mechanism described in Ahmadov et al. (2012). In the model, five volatility bins $\left(10^{-1}, 10^{0}, 10^{1}, 10^{2}, 10^{3} \mu \mathrm{g} \mathrm{m}^{-3}\right)$ are assumed for organic aerosols. For the computational efficiency of the model simulations, it is assumed that all the OA species in the first bin $\left(10^{-1} \mu \mathrm{g} \mathrm{m}^{-3}\right)$ are in the particle phase. The major modification to the SOA scheme here is the treatment of semi-volatile POA emissions. The WRF-Chem model with the updated SOA code allows assigning different volatility distributions for the POA emissions. Here, two scenarios for POA volatility are presented. In the base case scenario, POA is emitted with a volatility distribution similar to that of Tsimpidi et al. (2010), except that the distribution used to partition the POA emissions in this study conserves total POA mass.
Specifically, we used the following coefficients to partition the POA emissions across the five saturation bins: 0.09, 0.09, $0.14,0.18$, and 0.5 . In the other scenario, the POA is assumed to be non-volatile. Thus, in this scenario all the emitted POA remains in the particle phase in the atmosphere until it is removed by dry or wet deposition processes. Since there are large uncertainties related to the missing SVOC emissions in inventories, we did not scale up the POA emissions in this study. Therefore, total mass of the emitted POA is the same in both modeling scenarios.

Another major update to the model is the addition of intermediate VOCs (IVOCs). Unlike many other SOA modeling studies, we did not scale up the IVOC emissions according to the POA emissions. Here, the unidentified VOC emissions from the U.S. EPA NEI-2011v1 inventory were used as IVOCs. In WRF-Chem the IVOCs are emitted and transported as other gaseous species. They are oxidized by hydroxyl radical with the rate of $2.3 \times 10^{-11} \mathrm{~cm}^{3}$ molecule ${ }^{-1} \mathrm{~s}^{-1}$, as hexadecane. A similar approach was first applied in another WRF-Chem study in order to simulate SOA formation from the Deepwater Horizon oil spill in the Gulf of Mexico (Middlebrook et al., 2012b). As further discussed in Sect. 2.4, in the top-down emission simulation scenarios, IVOC emissions from the O\&G sector were scaled using the top-down estimates of the alkane species (namely the HC8 species in the RACM mechanism). Lack of direct measurements of ambient IVOC species makes it impossible to directly constrain their emissions using the top-down approach. Table 2 highlights differences in emission estimates and POA volatility assumptions used in the different simulation scenarios. In the simulation case with limited biogenic SOA formation, the first-generation semi-volatile organic condensable vapors are not oxidized further, and therefore only first-generation bVOC oxidation products contributed to biogenic SOA production.

The WRF-Chem model, which includes the new SOA formation mechanisms, was simulated on two domains, covering the contiguous United States (CONUS) and entire Colorado, at 12 and $4 \mathrm{~km}$ resolutions, respectively. In addition to the full gas and aerosol chemistry, a photolysis scheme, dry and wet removal parameterizations for both gaseous and aerosol species were incorporated in WRF-Chem. The anthropogenic and biogenic emissions were also included in the simulations. First, all the model simulations were conducted on the CONUS domain for the 24 July-14 August 2014 time period. Then, using a one-way nesting approach, initial and boundary conditions for the inner domain (Fig. S1 in the Supplement) were created to conduct various sensitivity simulations for 27 July-13 August. Simulations on the $4 \mathrm{~km}$ domain were conducted in $24 \mathrm{~h}$ intervals. The model was initialized by using meteorological input from the $12 \mathrm{~km}$ domain, which in turn used North American mesoscale analysis fields (www.emc.ncep.noaa.gov, last access: 21 July 2016) as boundary and initial conditions. Simulated chemical species were cycled between the $4 \mathrm{~km}$ domain runs to preserve the 
Table 2. Details on input parameters and assumptions used in the different WRF-Chem simulation scenarios.

\begin{tabular}{|c|c|c|c|}
\hline Case identifier & Emissions & POA volatility & $\begin{array}{l}\text { bVOC oxidation rate and } \\
\text { subsequent SOA formation }\end{array}$ \\
\hline BC-nOG & NEI, no O\&G & Semi-volatile & $k_{\mathrm{OH}}=1 \times 10^{-12} \mathrm{~cm}^{3}$ molec $^{-1} \mathrm{~s}^{-1}$ \\
\hline BC-tdOG & NEI, top-down O\&G & Semi-volatile & $k_{O H}=1 \times 10^{-12} \mathrm{~cm}^{3} \mathrm{molec}^{-1} \mathrm{~s}^{-1}$ \\
\hline nvPOA-nOG & NEI, no O\&G & Non-volatile & $k_{\mathrm{OH}}=1 \times 10^{-12} \mathrm{~cm}^{3}$ molec $^{-1} \mathrm{~s}^{-1}$ \\
\hline nvPOA-tdOG & NEI, top-down O\&G & Non-volatile & $k_{\mathrm{OH}}=1 \times 10^{-12} \mathrm{~cm}^{3}$ molec $^{-1} \mathrm{~s}^{-1}$ \\
\hline nvPOA-tdOG-bVOCox & NEI, top-down O\&G & Non-volatile & Limited formation of bSOA \\
\hline
\end{tabular}

fine-scale features captured by the inner domain. All the WRF-Chem modeling results presented here are based on the $4 \mathrm{~km}$ domain simulations. To determine model predictions along the flight track, the aircraft's flight track was traced in the model domain and measured parameters along this track were averaged over the model grid cells. The speed of the C-130 in the boundary layer with a full payload is $\sim 100 \mathrm{~m} \mathrm{~s}^{-1}$; thus, with the AMS averaging time of $15 \mathrm{~s}, 2-3$ values from the AMS measurements were available to average in a $4 \mathrm{~km} \times 4 \mathrm{~km}$ grid cell to compare the model to. There was no interpolation of the data in space or within the hourly temporal resolution of the model. Note also that there was no drastic variability within the hourly timescale of the modeled parameters.

\subsubsection{Emissions}

Since the focus of this paper is on quantification of SOA formation in the Front Range, two emission scenarios are explored. Both emissions scenarios are based on the U.S. EPA NEI-2011 emission inventory with the exception that O\&G activity emissions in the DJB are modified to allow direct quantification of SOA formation from this sector. The NEI-2011 emissions rely on the version 6.0 platform (https://www.epa.gov/air-emissions-modeling/ 2011-version-60-platform) and are basically the same emissions used and documented in Ahmadov et al. (2015) except for the chemical speciation profiles of the O\&G sectors. In some of the scenarios, all O\&G-related activity emissions are removed from the simulations. For other scenarios, VOC emissions from O\&G activity in the DJB are specified according to a top-down approach from observations collected at the Boulder Atmospheric Observatory (BAO) tower, on the western edge of the DJB. As previously mentioned, the "unknown" VOC species within the NEI-2011 inventory is also included, representing direct emissions of IVOCs. Summertime (July) conditions are assumed within the NEI temporal allocation specifications, as are the diurnal profiles and spatial allocations at $4 \mathrm{~km}$ horizontal resolution.

The top-down emissions from the DJB are derived using the same strategy as in Ahmadov et al. (2015), whereby $\mathrm{CH}_{4}$ flux observations over a basin are combined with basin-wide VOC to $\mathrm{CH}_{4}$ emission ratios. In this case, the O\&G activity sector $\mathrm{CH}_{4}$ flux estimate for May 2012 within the DJB of Petron et al. (2014) $\left(19.3 \pm 6.9 \mathrm{th}^{-1}\right)$ is adopted. VOC to $\mathrm{CH}_{4}$ emission ratios from $\mathrm{O} \& \mathrm{G}$ activity in the DJB for individual compounds are derived from VOC measurements at the BAO tower during the July-August 2012 SONNE (Summer Ozone Near Natural Gas Emissions) field study (https://www.esrl.noaa.gov/csd/ groups/csd7/measurements/2012sonne/, last access: 21 July 2016). Identical to the VOC analysis for the NACHTT2011 field campaign, linear regressions using two variables (propane and acetylene) are used to distinguish O\&G activity versus transportation-related sources (Gilman et al., 2013). Table $\mathrm{S} 1$ summarizes the correlation statistics of $\mathrm{NO}_{x}$ and 43 VOCs with $\mathrm{CH}_{4}, \mathrm{C}_{2} \mathrm{H}_{2}$, and $\mathrm{C}_{3} \mathrm{H}_{8}$ during SONNE. Derived emission ratios relative to propane are nearly identical between the two field studies for the 18 VOCs measured during NACHTT 2011 and are within $20 \%$ of the emission ratios of five of the VOCs from aircraft samples reported in Petron et al. (2014). All three DJB studies imply strong correlations between propane, $\mathrm{CH}_{4}$, and other VOCs from O\&G activity, allowing high confidence in the regression slopes that define the emission ratios used here. Spatial allocation and the area and point sector ratios of the top-down inventory are taken from the O\&G sector totals within NEI 2011, and no diurnal variation is assumed. As discussed in Gilman et al. (2013), $\mathrm{NO}_{x}$ and $\mathrm{CO}$ emissions from the oil and gas sector are indeterminable due to their overwhelming correlation with acetylene, so no $\mathrm{NO}_{x}$ or $\mathrm{CO}$ adjustments are possible in the topdown case. Likewise, no changes to NEI-2011 aerosol emissions are considered.

Table $3 \mathrm{a}$ and $\mathrm{b}$ provide emission totals from the NEI-2011 and the top-down VOC inventories for areas covering the DJB and Denver metro region, respectively. The DJB latitude and longitude limits in Table $3 \mathrm{a}$ are chosen to capture sources contributing to the $\mathrm{CH}_{4}$ emission totals within Petron et al. (2014), which also includes some northern suburbs of Denver. O\&G activity emissions are only included within "area" and "point" emission sector categories and are indeterminable within the mobile categories. The area category in particular dominates the ethane and unknown VOC emissions. We note that NEI 2011 does not specifically contain any POA emissions associated with O\&G activity. The largest area sources of POA in Table $3 \mathrm{a}$ are from agricul- 
Table 3. NEI-2011 emissions (July, weekday) for the Denver-Julesburg basin box, 39.8-40.7 N, 104.25-105.4 ${ }^{\circ} \mathrm{W}\left(9764 \mathrm{~km}{ }^{2}\right)$. Top-down estimates for $\mathrm{C}_{2} \mathrm{H}_{6}$ and toluene point and area sources are indicated. Units are kilo mole $\mathrm{h}^{-1}$ for gas-phase species and short tons day ${ }^{-1}$ for POC (primary organic carbon) and PNCOM (primary non-carbon organic matter).

\begin{tabular}{lrrrrr}
\hline (a) & \multicolumn{5}{c}{} \\
\hline Species & Total & Mobile on-road & Mobile non-road & Area & Point \\
\hline $\mathrm{NO}_{x}$ & 144.36 & 53.50 & 20.56 & 14.28 & 56.00 \\
$\mathrm{CO}$ & 874.37 & 366.07 & 426.84 & 11.76 & 69.70 \\
$\mathrm{C}_{2} \mathrm{H}_{6}$ & 232.34 & 0.56 & 0.57 & 221.93 & 9.28 \\
Toluene & 4.52 & 1.08 & 0.97 & 1.82 & 0.65 \\
Unknown & 1.87 & 0.15 & 0.00 & 1.35 & 0.36 \\
POC & 3.66 & 0.47 & 0.72 & 1.78 & 0.69 \\
PNCOM & 1.28 & 0.13 & 0.18 & 0.71 & 0.26 \\
\hline (b) & & & & & \\
\hline $\mathrm{NO}_{x}$ & 153.70 & 90.27 & 27.86 & 0.76 & 34.81 \\
$\mathrm{CO}$ & 1351.82 & 646.56 & 684.47 & 2.24 & 18.56 \\
$\mathrm{C}_{2} \mathrm{H}_{6}$ & 3.76 & 0.94 & 0.81 & 1.50 & 0.52 \\
Toluene & 4.61 & 1.86 & 1.47 & 0.75 & 0.53 \\
Unknown & 0.68 & 0.26 & 0.01 & 0.06 & 0.36 \\
POC & 4.53 & 0.79 & 1.04 & 2.37 & 0.33 \\
PNCOM & 1.55 & 0.21 & 0.26 & 0.95 & 0.13 \\
\hline
\end{tabular}

tural tilling, construction, and fugitives emissions from paved and unpaved roads, though commercial cooking sources account for $\sim 43 \%$. Emissions in the Denver metro region are dominated by mobile sources, while the main source of POA $(66 \%)$ is commercial cooking.

Based on the BEIS 3.14 inventory, biogenic emission sources are mostly in the south and west of Denver and over the mountains in western Colorado (Fig. S2). Since the typical daytime flow of air masses during FRAPPÉ was from east to west, it is apparent that transport of bVOCs into the Front Range compared to local sources was not significant.

\section{Results and discussion}

\subsection{Ambient OA observations}

Figure 1 highlights the general trends observed for $\mathrm{OA}$ vs. $\mathrm{CO}$ in the Front Range BL. Data points appear to be bound by enhancement ratios of $\triangle \mathrm{OA} / \triangle \mathrm{CO}=0.016$ $0.085 \mu \mathrm{g} \mathrm{m}^{-3} \mathrm{ppbv}^{-1}$, with higher values observed in air masses with $\mathrm{NO}_{x} / \mathrm{NO}_{y}<0.3$, i.e., air masses with a higher degree of photochemical processing, compared to fresher air masses with $\mathrm{NO}_{x} / \mathrm{NO}_{y}>0.7$. Note that these age categories best represent processing of plumes with $\mathrm{NO}_{x}$ emissions, while true aging of emissions in the absence of $\mathrm{NO}_{x}$ is not captured. Since daily flight patterns did not include regular upwind tracks, it was not possible to determine daily background values to subtract from the measured $\mathrm{OA}$ and $\mathrm{CO}$. Therefore, the enhancement ratios were determined by weighted, linear orthogonal distance regression

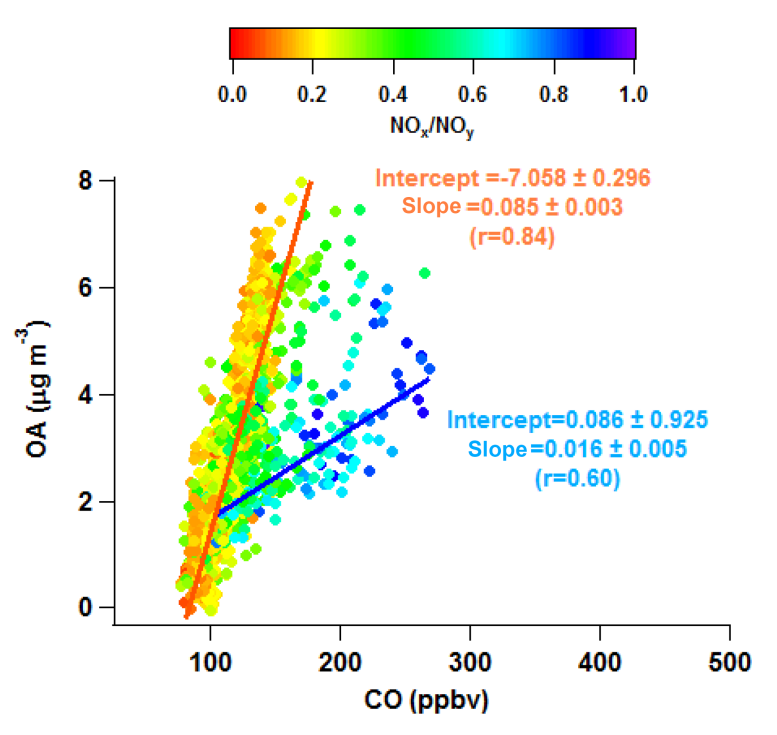

Figure 1. Scatter plot of OA against CO. The slopes are from weighted (by $30 \%$ uncertainty in OA and $3 \%$ uncertainty in $\mathrm{CO}$ ) orthogonal distance regression (ODR) fits to the data in relative fresh $\left(\mathrm{NO}_{x} / \mathrm{NO}_{y}>0.7\right)$ and aged $\left(\mathrm{NO}_{x} / \mathrm{NO}_{y}<0.3\right)$ plumes. The estimated uncertainties in the slope values represent $95 \%$ confidence intervals.

(ODR) fits, with weights representing the uncertainty in OA $(30 \%)$ and $\mathrm{CO}(3 \%)$. Uncertainties in the slopes represent $95 \%$ confidence intervals. Almost a factor of 5.5 increase in $\Delta \mathrm{OA} / \triangle \mathrm{CO}$ indicates a significant production of SOA with photochemical aging in the Front Range. Another notable feature in Fig. 1 is the higher $\Delta \mathrm{OA} / \Delta \mathrm{CO}$ enhancement ra- 


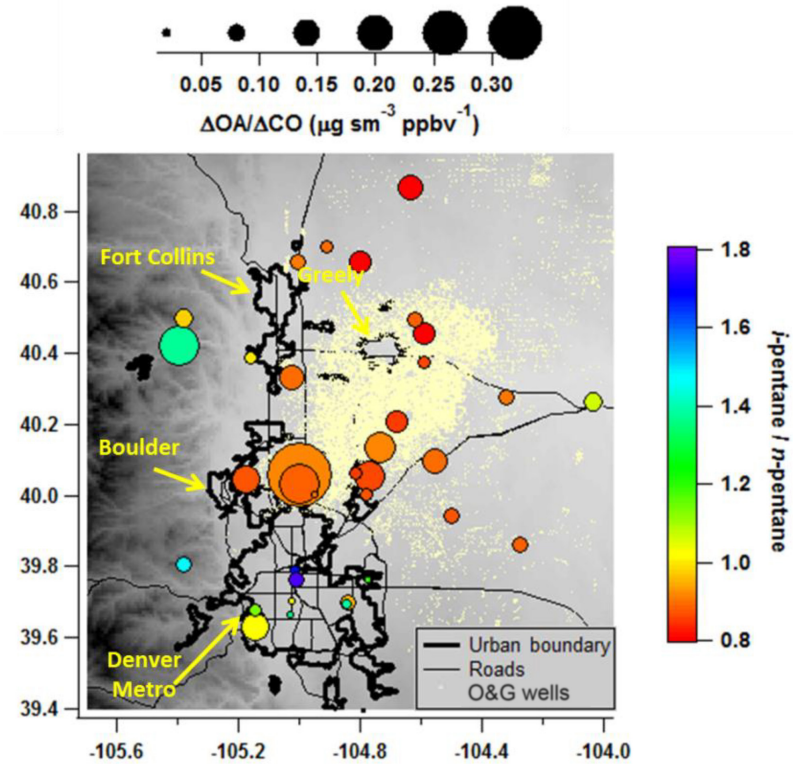

Figure 2. Enhancement ratios of OA with respect to $\mathrm{CO}$ in individual plumes sampled in the Front Range BL. Points are sized with $\Delta \mathrm{OA} / \Delta \mathrm{CO}$ and color coded by the $i$-pentane / $n$-pentane ratio. Only cases where the correlation coefficient $(r)$ of OA vs. CO was greater than 0.5 and the standard deviation of the ODR slopes was less than $50 \%$ of the slope itself are highlighted. Locations of O\&G wells are shown with yellow dots.

tio observed in the fresher plumes sampled in the Front Range compared to the typical enhancement ratio of primary $\mathrm{OA}$ to $\mathrm{CO}\left(\triangle \mathrm{POA} / \Delta \mathrm{CO} \sim 0.010 \pm 0.005 \mu \mathrm{g} \mathrm{m}^{-3} \mathrm{ppbv}^{-1}\right)$ observed in fresh air masses over other urban environments (de Gouw et al., 2008). This difference may arise from contributions of sources other than urban vehicular exhaust to POA in this region, as is further discussed below. Additionally, using the best estimates of the ODR slope and intercept values of the regression lines to the data, the predicated OA at background levels of $\mathrm{CO}(\sim 105 \mathrm{ppbv})$ was $1.82 \mu \mathrm{g} \mathrm{m}{ }^{-3}$. This value, which was very similar to the mode of the OA frequency distribution in the BL at $1.85 \mu \mathrm{g} \mathrm{m}^{-3}$, is a substantial portion of total OA, suggesting the presence of relatively high concentrations of non-combustion-related OA, likely of biogenic origin, in the region.

For a more detailed investigation of OA formation in different plumes, correlations of OA vs. $\mathrm{CO}$ in $\sim 94$ individual plumes in the boundary layer on 26 July-11 August were investigated to determine the corresponding $\triangle \mathrm{OA} / \triangle \mathrm{CO}$ values by the slope of weighted ODR fits. The spatial distribution of $\Delta \mathrm{OA} / \Delta \mathrm{CO}$ values, color-coded with the observed ratio of $i$ pentane / $n$-pentane, is summarized in Fig. 2 for cases where the correlation coefficient $(r)$ of OA vs. CO was greater than 0.5 and where the standard deviation of the ODR slopes was less than $50 \%$ of the slope itself. Urban emissions of the pentane isomers typically result in $i$-pentane / $n$-pentane values $>2$ (Warneke et al., 2007, 2013), while O\&G emissions in DJB have shown characteristic ratios $\sim 1$ (Petron et al., 2012; Gilman et al., 2013). Considering the location of the active O\&G wells in the Front Range (Fig. 2), the lower $i$ pentane/ $n$-pentane values observed to the north of the Denver metro area are a strong indicator for the influence of $O \& G$ emissions in these plumes. There are several plumes with a high $O \& G$ emission influence in this area that also display a large enhancement in OA with respect to CO. The apparent difference in the enhancement ratios may be due to the lower $\mathrm{CO}$ mixing ratios in the non-urban plumes or higher OA concentration in plumes sampled to the north of the Denver metro area, either because of longer photochemical age or higher concentrations of OA precursors in such plumes. We further investigate these differences in the next sections.

PMF analysis of the OA spectra resolved two distinct profiles with spectra shown in Fig. 3a. In the two-factor solution, the first factor had a higher contribution of $m / z 44$ and is identified as the secondary and oxygenated factor (OOA, oxygenated OA) as it correlated best with the OOA factor previously identified in several field studies (Ng et al., 2011) as well as secondary species such as sulfate and nitrate (Table 4). Increasing the number of factors resulted in split factors and a minimal decrease in $Q / Q_{\text {expected. When examin- }}$ ing correlation coefficients of two of the factors (in a threefactor solution case) containing signal at $m / z 44$ with external tracers, only the correlations with $\mathrm{CO}$ were significantly different ( $r=0.03$ vs. 0.28 ), while correlations with other anthropogenic and biogenic tracers (e.g., acetylene, ethane, isoprene oxidation products - i.e., methyl vinyl ketone and methacrolein - and monoterpenes) or aerosol nitrate and sulfate were not. We therefore believe that the three-factor solution is unable to determine a meaningful and independent third factor, and thus PMF is unable to clearly isolate the contribution of biogenic vs. anthropogenic sources to OOA in this environment. Statistically similar enhancement ratios of OOA relative to $\mathrm{CO}$ or odd oxygen $\left(\mathrm{O}_{x}\right)$ in aged (i.e., $\mathrm{NO}_{x} / \mathrm{NO}_{y}<0.3$ ) urban- and high-O\&G-influenced plumes were obtained (Fig. S3); however, median and mean OOA concentrations in plumes with a large influence of $O \& G$ emissions were $\sim 25 \%$ higher than the values in urban-only plumes, under similar non-cyclonic atmospheric conditions (Fig. 3c) (Sullivan et al., 2016; Vu et al., 2016). The uncorrelated relationship between OOA and $\mathrm{O}_{x}$ under cyclonic conditions in plumes with a high O\&G influence is similar to an observed large scatter in $\mathrm{CO}$ versus $\mathrm{O}_{3}$ (not shown). The influence of upwind sources of $\mathrm{CO}$ and OOA that were not correlated with $\mathrm{O}_{3}$ formation (e.g., biomass burning) cannot be ruled out under the cyclonic episodes sampled here, resulting in mean and median OOA values in O\&Ginfluenced plumes during cyclonic flow that were outside the variability range of the values observed during the noncyclonic flow. More discussion on the role of different emission sources on OA is presented in Sects. 3.2-3.3. Overall, the OOA factor dominated the OA composition, contributing to $85 \%$ of OA mass. The second factor, referred to as $\mathrm{HOA}$ 
Table 4. Correlation coefficient of PMF factors with different species.

\begin{tabular}{lrrrrrrr}
\hline & $\mathrm{CO}$ & Acetylene & $\mathrm{C}_{2} \mathrm{H}_{6}$ & $\mathrm{NO}_{3}^{-}$ & $\mathrm{SO}_{4}^{2-}$ & $\mathrm{HOA}^{\mathrm{a}}$ & $\mathrm{OOA}^{\mathrm{a}}$ \\
\hline Factor 1 - OOA & 0.68 & 0.71 & 0.46 & 0.64 & 0.69 & 0.50 & 0.95 \\
Factor 2 - HOA & 0.68 & 0.76 & 0.44 & 0.47 & 0.40 & 0.92 & 0.50 \\
\hline
\end{tabular}

${ }^{\mathrm{a}} \mathrm{HOA}$ and OOA factors as identified in Ng et al. (2011).

(hydrocarbon-like OA), had a pronounced fragmentation pattern at delta patterns 0 and 2 (e.g., $m / z 41,43,55,57,69,71$ ) that are common for hydrocarbons (McLafferty and Turecek, 1993) and correlated best with the HOA factor in previous field studies ( $\mathrm{Ng}$ et al., 2011) as well as primary combustion tracers such as acetylene and $\mathrm{CO}$; it therefore represents the fresh, hydrocarbon-like components of OA. Mean HOA concentrations were $\sim 35 \%$ higher (Fig. 3d) in high-O\&Ginfluenced plumes compared to urban plumes, under similar non-cyclonic conditions, suggesting contribution of primary aerosol (in this case, POA) emissions from equipment associated with O\&G-related activities (Field et al., 2014; Prenni et al., 2016). Averaged over all plume types, the contribution of HOA to total OA mass was $15 \%$. Although airborne measurements of aerosol optical extinction and $\mathrm{HCN}$ provided evidence for long-range transport of biomass burning plumes during 11-12 August (Dingle et al., 2016) to the Front Range, a factor with a significant contribution at fragments associated with levoglucosan combustion (i.e., $m / z 60$ and 73) was not identified. Therefore, either the contribution of wildfires to non-refractory OA composition during the days of PMF analysis was negligible or the photochemistry of the fire plumes during transport resulted in chemical transformation of the biomass burning markers (Hennigan et al., 2010, 2011).

\subsection{Influence of urban and O\&G emissions: measurements}

To better understand the impact of urban vs. O\&G emissions on SOA formation in the Front Range, data on measured OA, known precursors of SOA, and photochemical markers were examined in urban air masses and those with a high influence of O\&G emissions (Fig. 4). Mean and median values of OA were $\sim 40-48 \%$ higher in high-O\&G-influenced plumes compared to urban plumes. As discussed in Sect. 3.1 and Fig. 3, most of the OA in the Front Range is oxygenated and secondary in nature. More efficient SOA production in an air mass could be due to differences in oxidation timescales, amounts of SOA precursors or oxidants, or oxidation conditions, and thus SOA production yields. Statistical data in Fig. $4 b-d$ indicate that while the mixing ratio of biogenic species (sum of the measured isoprene, monoterpene, and $2 \times$ (methyl vinyl ketone and methacrolein)) in the two air mass types were similar within $20 \%$, the median mixing ratio of the sum of aromatic species (i.e., benzene, toluene, and
$\mathrm{C}_{8}$ and $\mathrm{C}_{9}$ aromatics) and sum of methylcyclohexane and $n$-octane, which are known SOA precursors (Odum et al., 1997a, b; Lim and Ziemann, 2005), were higher by factors of 2.4 and 4.7, respectively, in high-O\&G-influenced plumes relative to urban plumes. Therefore, it is not surprising that higher OA and OOA concentrations were measured in highO\&G-influenced plumes. Next, we examine photochemical conditions that affect SOA production yields. Radical chemistry in different $\mathrm{NO}_{\mathrm{x}}$ regimes leads to different SOA formation potentials, depending on the branching ratio of $\mathrm{RO}_{2}$ radicals reacting with $\mathrm{HO}_{2}$ vs. $\mathrm{NO}$ (Kroll et al., 2005; $\mathrm{Ng}$ et al., 2007a, b; Henze et al., 2008). Median NO mixing ratios in urban and high-O\&G plumes were at least 350 pptv (Fig. 4e), which is about a factor of 10 higher than the median $\mathrm{HO}_{2}$ mixing ratios in these plumes (Fig. 4f), suggesting that the oxidation conditions encountered in both urban- and highO\&G-influenced air masses were NO-rich, and hence provide the conditions where $\mathrm{RO}_{2}$ radicals predominantly react with $\mathrm{NO}$ rather than $\mathrm{HO}_{2}$ radicals. Furthermore, mean and median $\mathrm{OH}$ concentrations in both urban- and high-O\&Ginfluenced plumes were similar to within $\sim 15 \%$. The dominance of $\mathrm{NO}$ over $\mathrm{HO}_{2}$ and lack of a significant difference in $\mathrm{OH}$ concentrations in urban- and high-O\&G-influenced air masses indicate the presence of similar oxidation conditions in the two air mass types. Thus, the higher OA values in highO\&G-influenced plumes compared to pure urban plumes are hypothesized to be due to SOA formation from higher concentrations of aromatics and larger alkanes. We further investigate the contribution of O\&G sources to SOA formation in simulation scenarios with WRF-Chem modeling.

\subsection{Influence of urban and O\&G emissions: modeling}

\subsubsection{WRF-Chem simulations of gaseous species}

We begin examining the results of WRF-Chem simulation runs by first comparing predicted mixing ratios of various primary and secondary gases in urban- and high-O\&Ginfluenced air masses. This exercise was not performed as a point and point comparison along the flight track since locations of the simulated pollution plumes were sometimes shifted compared to the measurements. An example of differences between the measured and modeled distribution of plumes is shown for ethane in Fig. S4. Because of this, flags similar to those used for characterizing plumes measured with urban and high O\&G emissions were defined, based on 
(a)

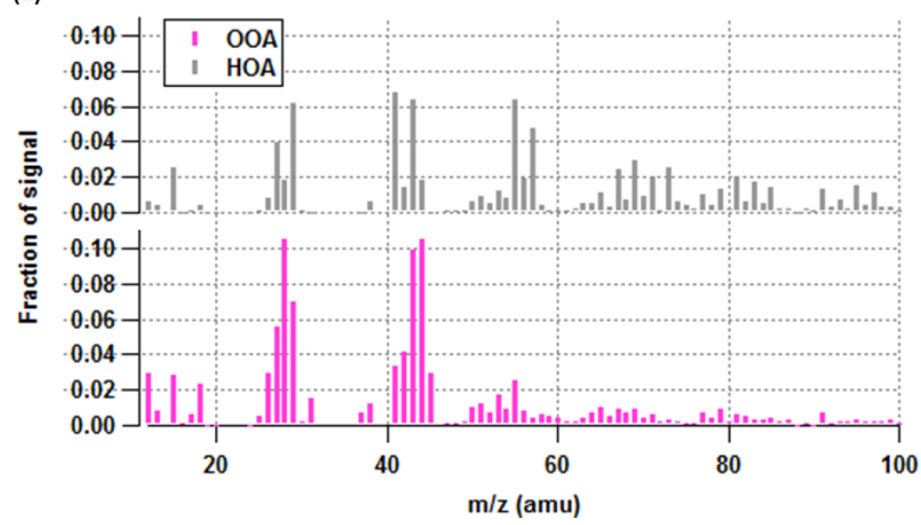

(b)
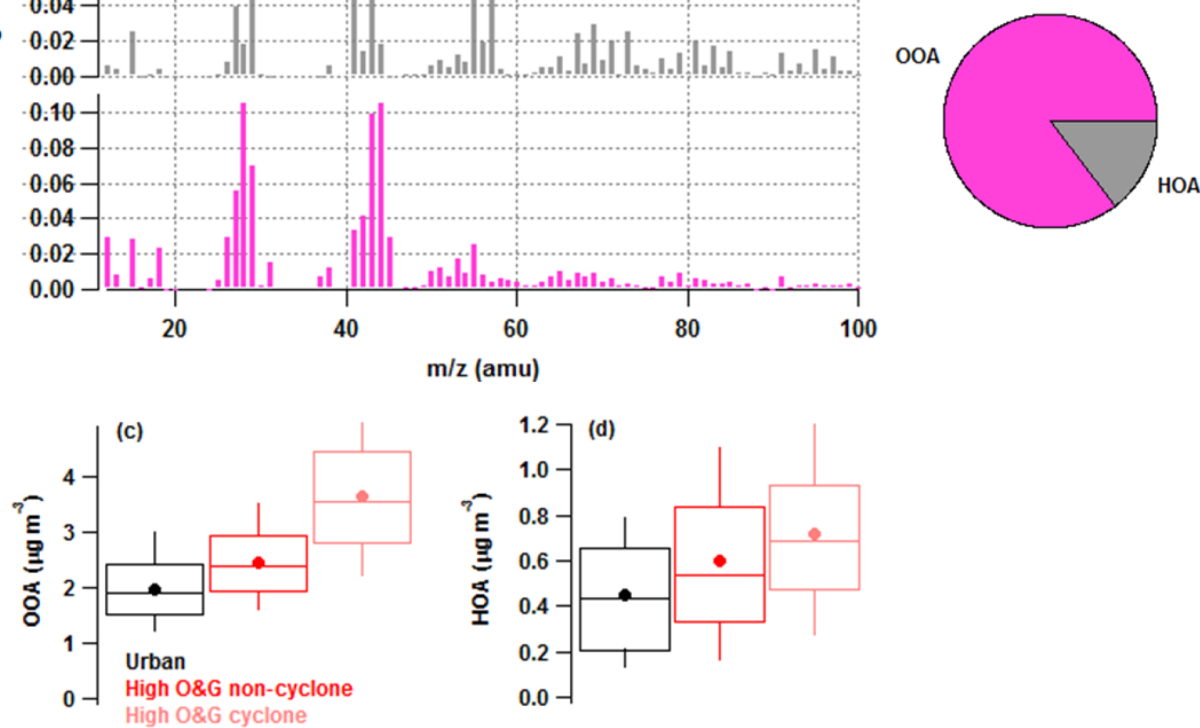

Figure 3. Mass spectra (a), fractional contribution (b), and mass concentrations of OOA (c) and HOA (d) factors. Box and whisker plots depict the 10th, 25th, 50th, 75th, and 90th percentiles. Mean values of OOA and HOA in each plume type are shown in circles.
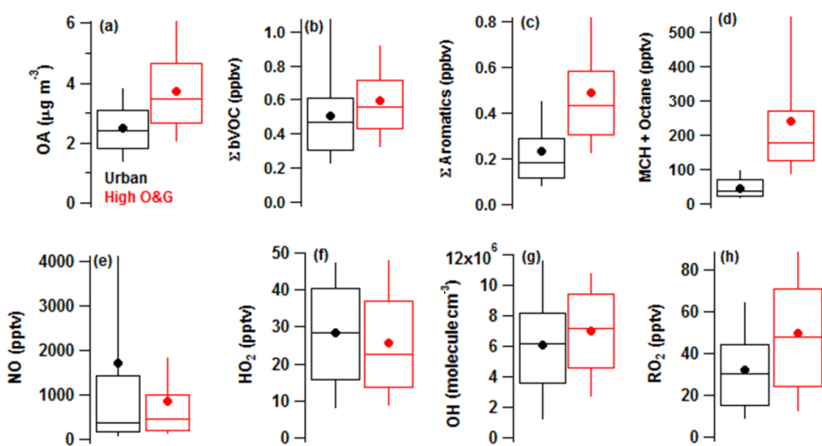

Figure 4. Statistical analysis of measured OA (a), various hydrocarbons (sum of biogenic VOCs, bVOC, defined as isoprene $+2 \times$ (methyl vinyl ketone + methacrolein) + monoterpenes $(\mathbf{b})$; sum of aromatic VOCs defined as benzene + toluene $+\mathrm{C}_{8}$ aromatics $+\mathrm{C}_{9}$ aromatics (c); sum of methylcyclohexane and octane (d)), NO (e), and radicals $\left(\mathrm{HO}_{2}(\mathbf{f}), \mathrm{OH}(\mathbf{g})\right.$, and $\left.\mathrm{RO}_{2}(\mathbf{h})\right)$ in urban- and highO\&G-influenced plumes. Box and whisker plots depict the 10th, 25th, 50th, 75th, and 90th percentiles. Mean values in each plume type are shown in circles.

the modeled values of $\mathrm{CO}$ and $\mathrm{C}_{2} \mathrm{H}_{6}$, and statistical analyses of data under each flag type were carried out. To assess the impact of the emission scenarios, we first compare measured and modeled values of $\mathrm{C}_{2} \mathrm{H}_{6}$, toluene, and $\mathrm{CO}$ in urban- and high-O\&G-influenced air masses. Figure $5 \mathrm{a}-\mathrm{b}$ demonstrate that there is a large influence of $\mathrm{C}_{2} \mathrm{H}_{6}$ from the $\mathrm{O} \& \mathrm{G}$ sector in the Front Range and that neglecting those emissions sig- nificantly underestimates $\mathrm{C}_{2} \mathrm{H}_{6}$ mixing ratios in both urbanand high-O\&G-influenced plumes. In urban plumes (Fig. 5c, e), the mean toluene and $\mathrm{CO}$ mixing ratios were very similar under both emission scenarios and overestimated compared to the measurements by a factor of 2 and $20 \%$, respectively. In the high-O\&G-influenced plumes (Fig. 5b, d, f), neglecting the $\mathrm{O} \& \mathrm{G}$ emissions of VOCs resulted in underestimation of $\mathrm{C}_{2} \mathrm{H}_{6}$ (by a factor $>10$ ) and toluene (by $35 \%$ ) and $\sim 10 \%$ overestimation of $\mathrm{CO}$ compared to the measurements. When modifying the $\mathrm{O} \& \mathrm{G}$ emissions with the top-down approach, a reasonable comparison for $\mathrm{C}_{2} \mathrm{H}_{6}$ was achieved in the high-O\&G-influenced plumes; additionally, the mean toluene mixing ratio was now within $12 \%$ of the measurements while the mean values for $\mathrm{CO}$ did not change. These comparisons demonstrate that adjusting the O\&G sector emissions by the top-down approach was necessary to realistically capture the influence of such emissions in the Front Range.

We next compare the mixing ratios of biogenic SOA precursors with the modified NEI emissions. Since emissions of biogenic VOCs were not modified in the top-down approach and because one goal of the current study is to investigate the contribution of $\mathrm{O} \& \mathrm{G}$ emissions to $\mathrm{OA}$ formation, we focus on the comparison between the measured values and only the modified, top-down O\&G emission scenario (Fig. 6). These comparisons suggest that isoprene and its oxidation products are well represented in the model, whereas the monoterpene mixing ratios are underestimated by as much as $50 \%$. The effect of this underestimation on total SOA formation however 

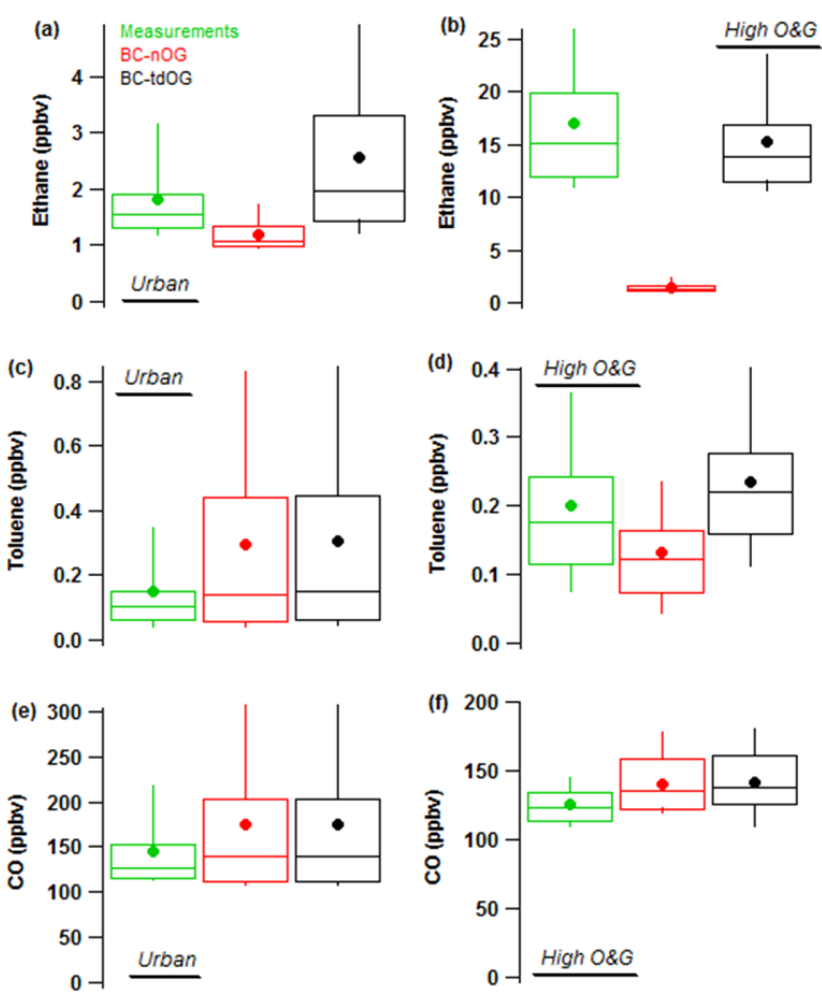

Figure 5. Comparison of the measured and WRF-Chem-predicted (no $O \& G$ and top-down $O \& G$ emission scenarios) mixing ratios of ethane ( $\mathbf{a}$ and $\mathbf{b}$ ), toluene (c and $\mathbf{d}$ ), and CO (e and $\mathbf{f}$ ) in urbanand high-O\&G-influenced plumes. Box and whisker plots depict the 10 th, 25th, 50th, 75th, and 90th percentiles. Mean values are shown in circles.

may not be significant given the very low measured monoterpene mixing ratios (average and median values of $\sim 40 \mathrm{pptv}$ ).

Overall, measured and predicted $\mathrm{OH}$ concentrations in urban- and high-O\&G-influenced plumes compared very well with the top-down estimates of O\&G emissions (Fig. 7a-b). Mean and median $\mathrm{OH}$ concentrations without $\mathrm{O} \& \mathrm{G}$ emissions were overestimated in O\&G-influenced plumes by $\sim 40 \%$. Mean and median values of $\mathrm{HO}_{2}$ were predicted very well in the high-O\&G-influenced plumes regardless of the emission scenario, but with a lower degree of variability compared to the measurements. Median and mean values of the measured urban $\mathrm{HO}_{2}$ were about twice as much as the predicted values. However, given the measurement uncertainty levels (up to $35 \%$ ), the comparison is still very good (Fig. 7c-d). Predicted mean and median NO mixing ratios in urban plumes compared well with the measurements, while the high NO values in plumes with a high influence from $\mathrm{O} \& \mathrm{G}$ emissions were not predicted well, resulting in $60 \%$ lower mean $\mathrm{NO}$ values in these plumes (Fig. 7ef). Since NO emissions from the O\&G sector remained the same in the different scenarios, comparisons with only one scenario are shown here.
Measured and predicted values of $\mathrm{O}_{3}$ are compared in Fig. 8. Without emissions from the O\&G sector, mean predicted $\mathrm{O}_{3}$ values in urban- and high-O\&G-influenced plumes were $\sim 8.5 \mathrm{ppbv}$ and $\sim 2$ ppbv lower than measurements. The higher discrepancy observed in urban plumes might be due to overestimation of primary urban emissions (e.g., toluene, $\mathrm{CO}$, and $\mathrm{NO}$ ) and subsequently higher $\mathrm{O}_{3}$ titration by NO, or due to lower extent of mixing in the model. In simulations including the $\mathrm{O} \& \mathrm{G}$ emissions, a minor $(<1 \mathrm{ppbv})$ increase in the mean urban $\mathrm{O}_{3}$ was predicted while the increase in high-O\&G-influenced plumes was more significant, at $\sim 4.5 \mathrm{ppbv}$. It should be noted that the uncertainties in meteorological simulations (e.g., wind speed and direction) also contribute to the overall model-measurement discrepancies of the chemical species discussed here.

\subsubsection{WRF-Chem simulations of organic aerosol}

In this section we examine simulated values of different $\mathrm{OA}$ types in the different simulation runs and compare them with the factors resolved by PMF. The cumulative distributions of PMF-derived HOA and simulated POA concentrations in the Front Range boundary layer are shown in Fig. 9a. It is apparent that the median value of POA in the base case and all the runs using a similar volatility assumption of POA is significantly lower than the HOA estimate derived from PMF. It is worth noting that cooking POA contributions in NEI might be underestimated for the Front Range area, while there could be some contribution of POA from cooking or sources other than vehicular exhaust to the PMF-resolved HOA factor. For example, as shown in Fig. 3d and discussed previously, there appears to be some contribution to HOA from O\&G-related activities. A higher POA emission factor from O\&G-related activities is not unexpected given typically high emissions from diesel engines without after-treatment technology that might be working at these sites (Ban-Weiss et al., 2008; Jathar et al., 2017); however, as mentioned before, there were no adjustments to POA emissions for the O\&G sector in WRF-Chem when modifying the top-down estimates of gaseous emissions. Despite this, it is unlikely that NEI emission factors of POA from the urban areas are underestimated by up to a factor of 8 (mean HOA $\sim 0.45 \mu \mathrm{g} \mathrm{m}^{-3}$ vs. mean POA $\sim 0.05 \mu \mathrm{g} \mathrm{m}^{-3}$ ). One possible explanation for this discrepancy is the assumed volatility distribution of the POA. Given the large uncertainties in volatility estimates of POA from different sources (Hodzic et al., 2010b; May et al., 2013), to explore the effect of POA volatility, simulations were repeated assuming non-volatile POA. In these runs and regardless of $O \& G$ emission treatments, the mean and median POA values increased by a factor of 5, bringing the predicted POA values within a factor of 2 of the PMF-based HOA concentrations. The non-volatile POA assumption may not be accurate, and improved volatility distributions of POA from different combustion sources would have to be considered to accurately account for the semi-volatility of POA 

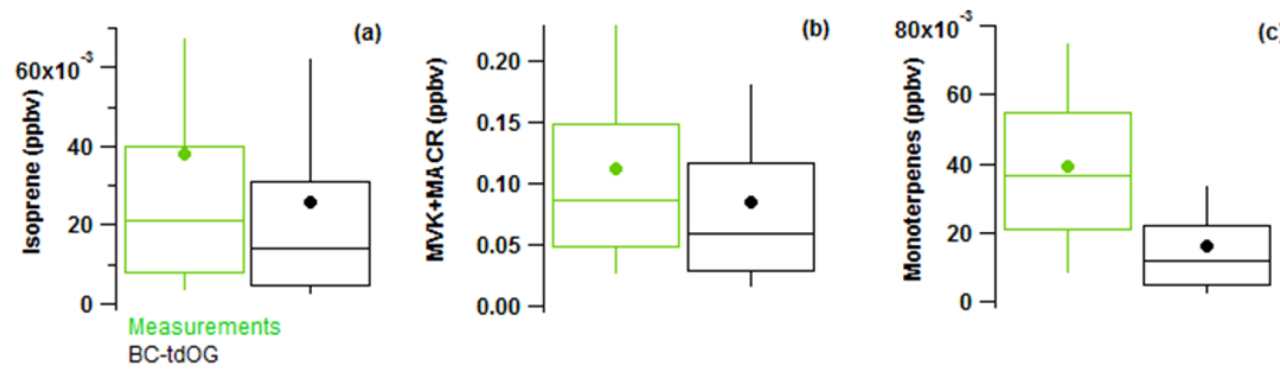

Figure 6. Comparison of the measured and WRF-Chem-predicted (top-down O\&G emission scenario) mixing ratios of isoprene (a), methyl vinyl ketone (only available in measurements) and methacrolein (b), and monoterpenes (c) in the Front Range boundary layer. Box and whisker plots depict the 10th, 25th, 50th, 75th, and 90th percentiles. Mean values are shown in circles.
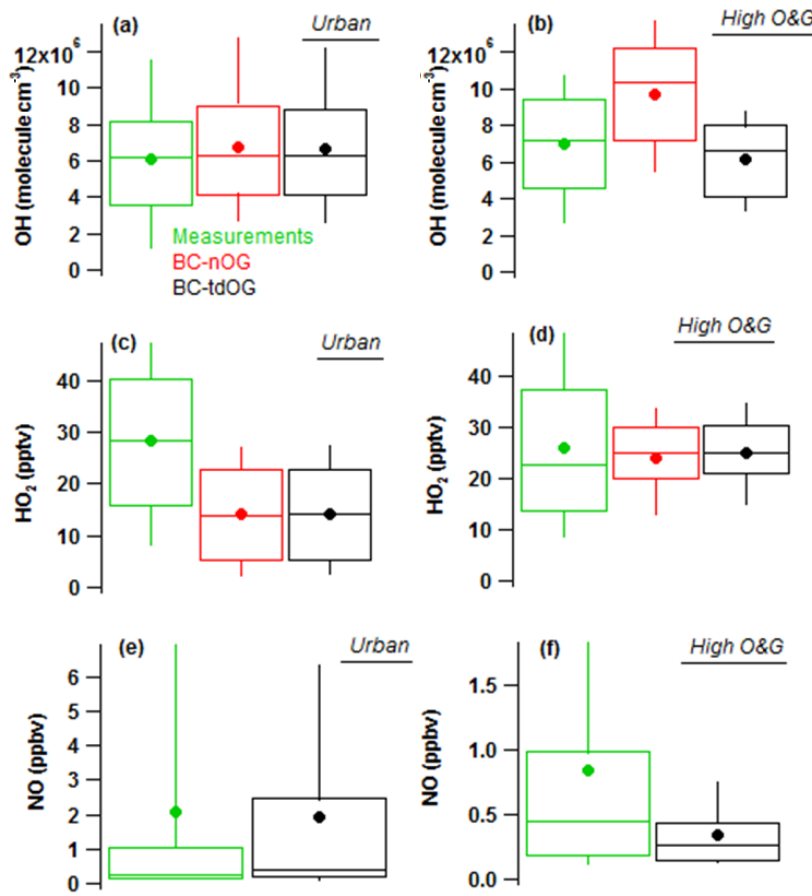

Figure 7. Comparison of the measured and WRF-Chem-predicted (no $\mathrm{O} \& \mathrm{G}$ and top-down $\mathrm{O} \& \mathrm{G}$ emission scenarios) amounts of $\mathrm{OH}$ (a and b), $\mathrm{HO}_{2}$ (c and d), and $\mathrm{NO}$ in urban- and high-O\&Ginfluenced plumes. Box and whisker plots depict the 10th, 25th, 50th, 75th, and 90th percentiles. Mean values are shown in circles.

emissions in future air quality models. However, in the absence of better estimates of POA emission ratios or volatility, the predicted POA values in current simulations with nonvolatile POA conditions are more comparable to the PMFbased estimates of HOA in this environment.

Modeled total OA values in the Front Range BL are compared with the observed values in Fig. 9b. The median values of most model scenarios, except when biogenic aging was turned off, were $\sim 35 \%$ higher than measurements, which is an excellent agreement considering the uncertainties in measurements, emissions (magnitude and speciation), meteoro-
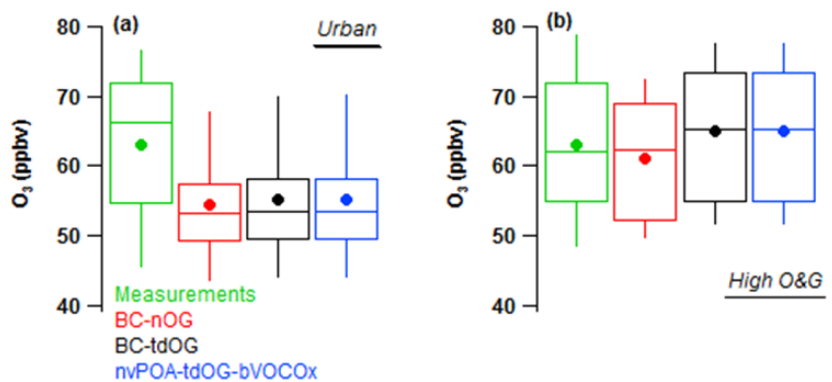

Figure 8. Comparison of the measured and WRF-Chem-predicted mixing ratios of ozone in urban-influenced (a) and high-O\&Ginfluenced (b) plumes. Box and whisker plots depict the 10th, 25th, 50th, 75th, and 90th percentiles. Mean values are shown in circles.

logical simulations, and other input parameters of the model. The extremely low and high values of measured OA, however, were not predicted well with any of the model runs, likely due to uncertainties in emissions of IVOCs from the urban and O\&G sector as well as uncertainties in the aging mechanisms of hydrocarbons (e.g., extent of fragmentation vs. functionalization reactions or aging of biogenic SVOC products). Measured and modeled total OA values in urbanand O\&G-influenced plumes are compared in Fig. 10a-b. Regardless of model assumptions, predicted median values of OA were 0.6 to $1.8 \mathrm{\mu g} \mathrm{m}^{-3}$ ( 25 to $58 \%$ ) higher than the measured median values in urban plumes. This overprediction may partly stem from higher-than-measured mixing ratios of urban VOCs in the model (Fig. 5c). Comparisons in the high-O\&G-influenced plumes were better, with differences of only -0.2 to $0.8 \mu \mathrm{g} \mathrm{m}^{-3}$ ( -6 to $25 \%$ ) between measured and predicted values. Consistent with the observations in Fig. 9b, there was a bias towards higher values in the modeled urban OA while the measured high values in O\&Ginfluenced plumes were underpredicted.

The effect of POA volatility was most apparent in predicted OA values in the urban plumes. Considering results of pairs of runs with similar consideration of $\mathrm{O} \& \mathrm{G}$ emissions, non-volatile POA runs resulted in a $\sim 13 \%\left(\sim 0.4 \mu \mathrm{g} \mathrm{m}^{-3}\right)$ increase in total OA compared to scenarios where POA 

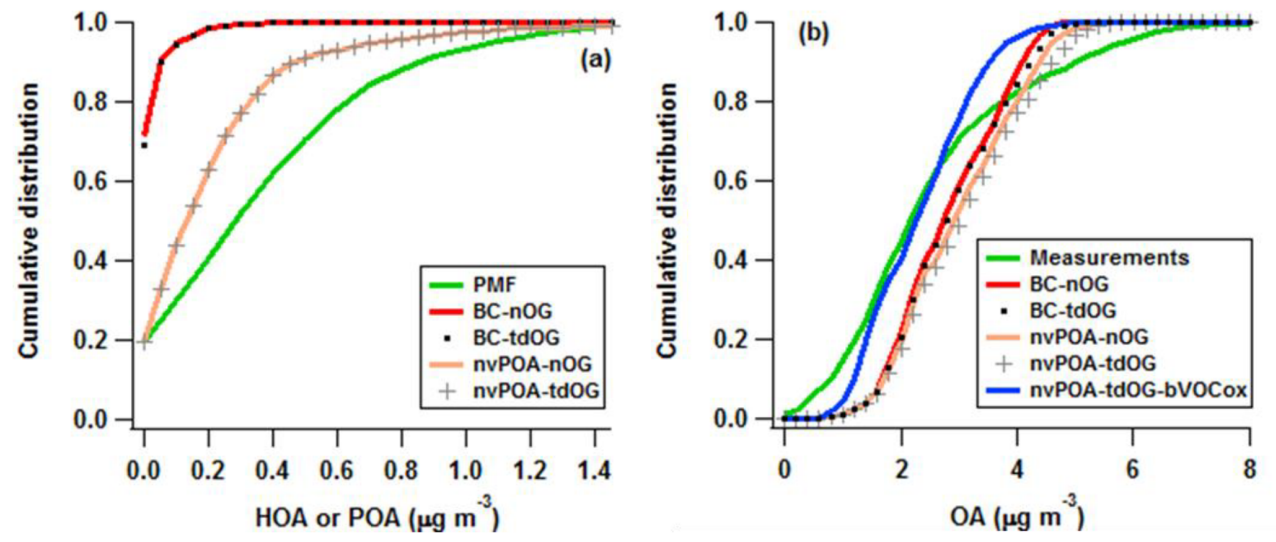

Figure 9. Cumulative distribution of HOA or POA (a) and OA (b) based on measurements and various simulation scenarios.
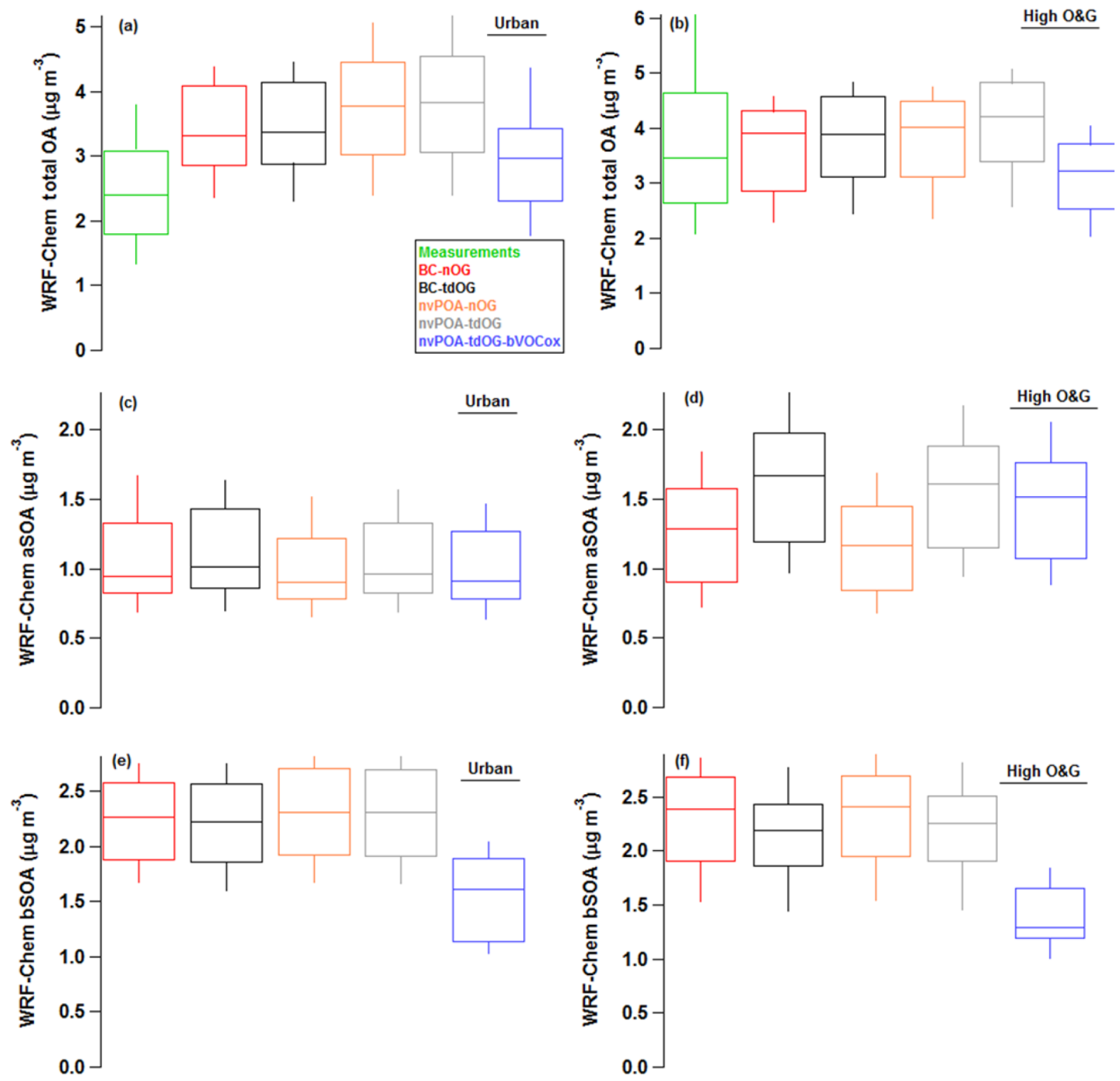

Figure 10. Statistical comparisons of predicted OA, anthropogenic SOA (aSOA), and biogenic SOA (bSOA) in urban-influenced (a, c, e) and high-O\&G-influenced (b, d, e) plumes in different model scenarios. Data from measured OA are also included in (a-b). Box and whisker plots depict the 10th, 25th, 50th, 75th, and 90th percentiles. 


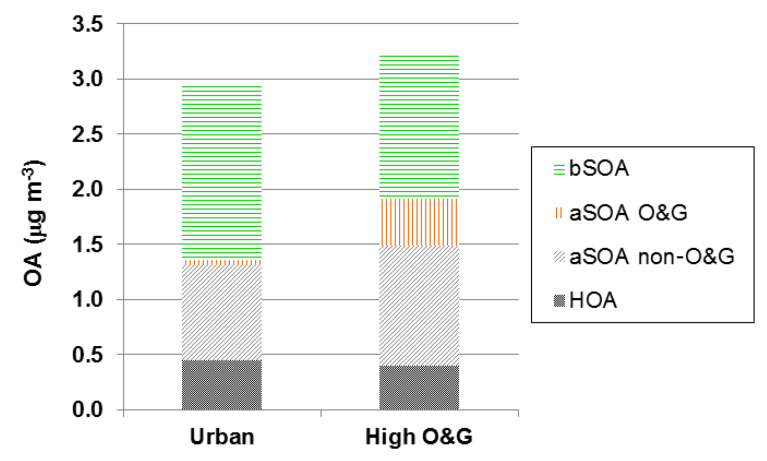

Figure 11. Contributions from $\mathrm{HOA}$, aSOA (non-O\&G and $\mathrm{O} \& \mathrm{G}$ sources), and bSOA to total OA as predicted by WRF-Chem in the case with non-volatile POA and limited bSOA formation assumptions.

was assumed to be semi-volatile (Fig. 10a). To determine how different components of OA were affected by changes in POA volatility, anthropogenic and biogenic SOA values (aSOA and bSOA, respectively) were considered separately. Assuming POA was non-volatile actually reduced aSOA by $<5 \%\left(\sim 0.05 \mu \mathrm{g} \mathrm{m}^{-3}\right)$ in urban plumes (Fig. 10c) while it increased bSOA by $2-4 \%\left(0.04-0.08 \mu \mathrm{g} \mathrm{m}^{-3}\right)$ (Fig. 10e). The reason for the reduction in aSOA is that with the nonvolatile assumption of POA its semi-volatile components are not available for gas-phase oxidation, reducing concentrations of anthropogenic oxidized species that are condensable and thus leading to a decrease in aSOA. On the other hand, since POA concentration is higher when assumed nonvolatile, available aerosol mass for absorptive partitioning is higher, resulting in increased partitioning of semi-volatile bVOC oxidation products to the aerosol phase and thus an increase in bSOA concentration. Therefore, it appears that most of the increase in urban total OA in non-volatile POA scenarios is due to the contribution from POA.

The effect of including top-down estimates of O\&G emissions on predicted OA was quantified from changes in predicted OA, under the same POA volatility assumption, in the high-O\&G-influenced plumes. Results indicate at most a $4.7 \%$ increase in OA from O\&G emissions. Although the net increase in $\mathrm{OA}$ due to $\mathrm{O} \& \mathrm{G}$ emissions was relatively small, there was a $\sim 30-38 \%\left(\sim 0.4 \mu \mathrm{g} \mathrm{m}^{-3}\right)$ increase in aSOA due to these emissions, depending on POA volatility. On the other hand, median bSOA values decreased by $8-10 \%\left(<0.2 \mu \mathrm{g} \mathrm{m}^{-3}\right)$ after including the top-down estimates of $\mathrm{O} \& \mathrm{G}$ emissions, likely due to reductions in $\mathrm{OH}$ with the additional VOC emissions in the high-O\&G-influenced plumes (Fig. 7b).

As apparent in the cumulative distribution of OA (Fig. 9b), the model cases discussed so far do not capture $\sim 10 \%$ of the data where measured OA values are lower than $1 \mu \mathrm{g} \mathrm{m}{ }^{-3}$, suggesting that the background OA in these runs might be overpredicted. A final model run was designed to investigate the role of successive biogenic VOC aging on the pre- dicted OA and its background values. Although the lowconcentration OA data points were still overpredicted in this model run (Fig. 10), the overall comparisons with the observed OA values (Fig. 10a, b) were best when consecutive formation of bSOA was turned off. Specifically, total predicted OA values in these run were $0.8-1 \mu \mathrm{g} \mathrm{m}^{-3}$ lower than the scenarios with similar POA volatility and O\&G emissions while consecutive formation of bSOA was active. This decrease was predominantly due to the decrease in the bSOA portion of OA (Fig. 10e-f). It is worth highlighting that even with these reduced $\mathrm{bSOA}$ values, the predicted contribution of bSOA to total OA in the Front Range remained high, at $\sim 54$ and $40 \%$ in urban- and O\&G-influenced plumes, respectively (Fig. 11). This is qualitatively consistent with the relatively high values of $\mathrm{OA}$ at background $\mathrm{CO}$ mixing ratios as was shown in Fig. 1.

We further examine simulations of SOA formation in two scenarios with non-volatile POA. With the standard treatment of bVOC oxidation and bSOA formation, urban plumes with $\mathrm{NO}_{x} / \mathrm{NO}_{y} n<0.3$ displayed a $50 \%$ greater enhancement in SOA with respect to $\mathrm{CO}(\Delta \mathrm{SOA} / \Delta \mathrm{CO})$ compared to plumes with a high O\&G influence (Fig. 12a). On the other hand, SOA enhancement with respect to $\mathrm{O}_{x}\left(\Delta \mathrm{SOA} / \Delta \mathrm{O}_{x}\right)$ was $30 \%$ higher in high-O\&G-influenced plumes (Fig. 12c). By turning off consecutive formation of bSOA, similar $\triangle \mathrm{SOA} / \triangle \mathrm{CO}$ enhancement ratios were obtained in urbanand high-O\&G-influenced plumes (Fig. 12b) while the difference in $\Delta \mathrm{SOA} / \Delta \mathrm{O}_{x}$ increased, with the ratio in highO\&G-influenced plumes being $\sim 66 \%$ higher than in urban plumes (Fig. 12d). Both of these trends are consistent with reductions in bSOA in urban plumes. Neither of the simulation scenarios resulted in $\Delta \mathrm{SOA} / \Delta \mathrm{CO}$ values similar to the observed $\triangle \mathrm{OOA} / \triangle \mathrm{CO}$ in urban plumes, although the predicted values in high-O\&G-influenced plumes were consistent with the lower values of the ODR fits to the observations considering the $95 \%$ confidence intervals (Fig. S3). It is worth noting that not considering variable background levels of OOA and $\mathrm{CO}$ and the uncertainties associated with PMF analysis might have also impacted the comparisons discussed here. Simulated $\Delta \mathrm{SOA} / \Delta \mathrm{O}_{x}$ were also significantly lower than observed $\triangle \mathrm{OOA} / \Delta \mathrm{O}_{x}$ in urban plumes indicating that neither runs predicted an accurate relationship for SOA and $\mathrm{O}_{x}$ formation in these plumes, despite predicting OA well. Contrary to the measurements, predicted $\mathrm{CO}$ (Fig. 5e-f), NO (Fig. 7e-f), and $\mathrm{O}_{3}$ (Fig. 8a-b) mixing ratios were different in urban- and high-O\&G-influenced plumes, therefore contributing to some of the differences in predicted $\triangle \mathrm{SOA} / \Delta \mathrm{CO}$ and $\Delta \mathrm{OOA} / \Delta \mathrm{O}_{x}$ in urban-influenced vs. O\&G-influenced plumes.

\section{Conclusions and implications}

Summertime OA in the Front Range displayed significant enhancement with respect to $\mathrm{CO}$ in photochemically aged 

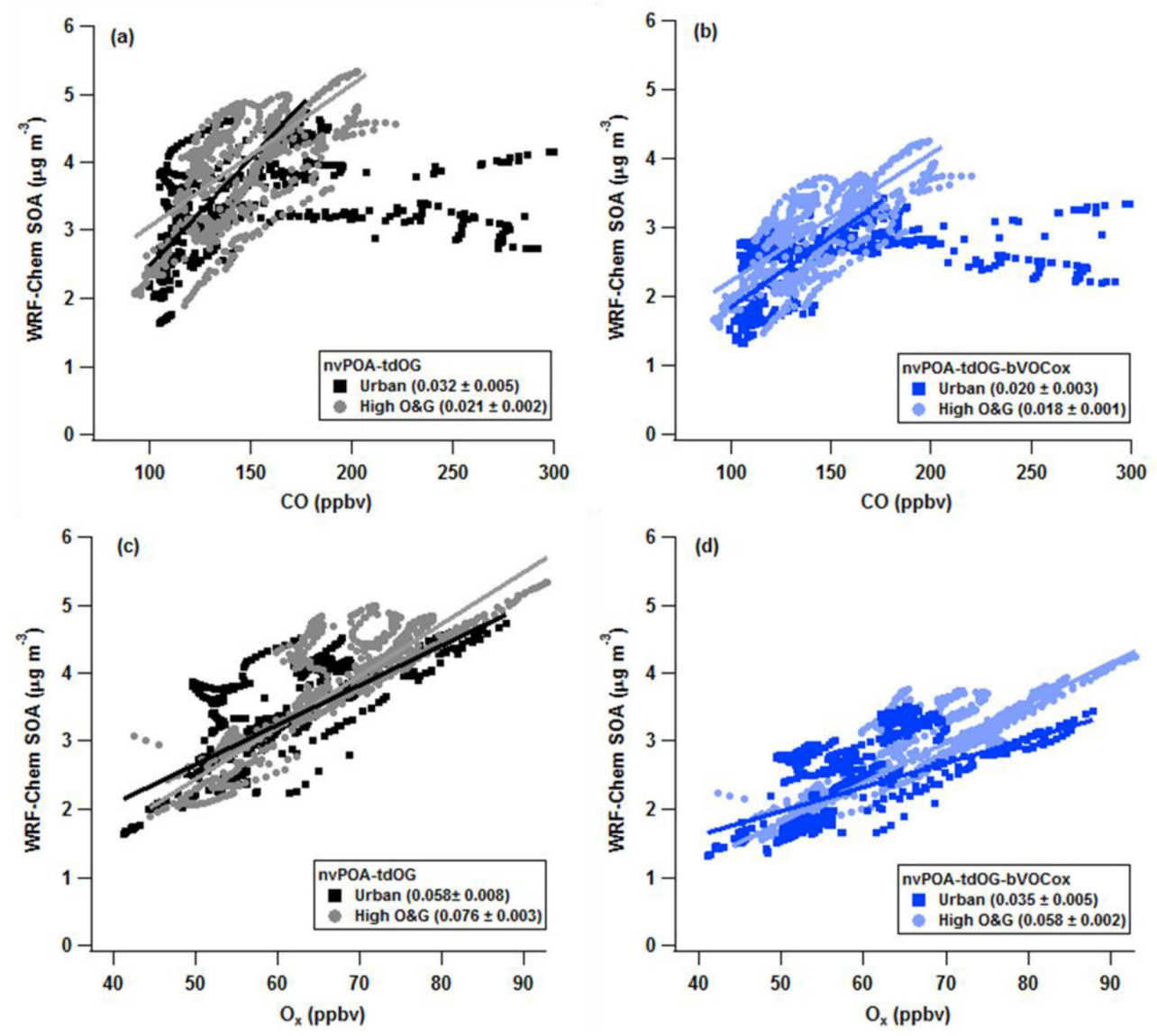

Figure 12. Correlation plots of predicted SOA against $\mathrm{CO}(\mathbf{a}-\mathbf{b})$ and odd oxygen, $\mathrm{O}_{x}$, defined as $\mathrm{O}_{3}+\mathrm{NO}_{2}$ (c-d) for model runs with non-volatile POA and top-down estimates of O\&G emissions when biogenic SOA aging was turned on (a and $\mathbf{c})$ and off (b and $\mathbf{d})$. ODR slope values indicated in parenthesis are obtained considering data when simulated $\mathrm{NO}_{x} / \mathrm{NO}_{y}<0.3$.

plumes. Substantial contributions of OOA in plumes impacted by urban and $O \& G$ emissions were confirmed with PMF analysis. In the absence of cyclonic flow and under similar atmospheric conditions, differences in OOA and HOA concentrations in urban-influenced vs. high-O\&G-influenced plumes were within the observed variabilities while mean and median concentrations of OOA were significantly higher during the Denver cyclone. Mixing ratios of aromatics, methyl cyclohexane, octane, and $\mathrm{RO}_{2}$ radicals were significantly higher in high-O\&G-influenced plumes compared to urban plumes. Despite this, $\mathrm{OH}$ and $\mathrm{HO}_{2}$ mixing ratios were highly similar.

To assess the role of O\&G emissions on SOA production, WRF-Chem model runs were carried out, with different considerations for POA volatility and emission strengths from the $\mathrm{O} \& \mathrm{G}$ sector. Assuming a semi-volatile nature for POA resulted in greater than factor of 10 lower mean and median POA concentrations compared to the PMF-based HOA, while simulations with the assumption of non-volatile POA resulted in only a factor of 2 lower POA compared to HOA. Assuming non-volatile POA increased the predicted total OA by $\sim 13 \%$, mainly through additional contribution of POA to OA. Much improved comparisons between predicted mixing ratios of VOCs and the measurements were achieved when using top-down modified emission factors from the O\&G sector in DJB. Overall, comparisons of the median measured and predicted OA were satisfactory, with the best match obtained in runs when consecutive aging of bVOCs and bSOA formation was turned off. The extent of SOA formation due to emissions from the O\&G sector was estimated to be less than $5 \%$ of total OA; however, the contribution of O\&G emissions to aSOA was more significant at $\sim 30-38 \%$. Given the uncertainties in emissions of IVOCs from the O\&G sector, more simulations need to be carried out to better quantify the contribution of O\&G IVOC emissions to total OA. In addition, it is important to characterize POA emissions associated with the O\&G sector in future emission inventories. A large fraction $(\sim 40-54 \%)$ of OA in the Front Range was predicted to be from bSOA. Uncertainties in photochemical processing and aging of bVOCs also warrant additional studies to constrain the production of bSOA. It is worth noting that, in the wintertime with lower boundary layer heights 
and lower temperatures, higher aerosol mass and more favorable conditions for the partitioning of semi-volatile species to the aerosol phase exist. Additionally, significantly lower emissions of bVOCs are expected in wintertime; therefore, contributions of O\&G emissions to SOA in the Front Range could be more significant than what was observed during this study.

Data availability. Data used in this analysis are available at http://www-air.larc.nasa.gov/cgi-bin/ArcView/discover-aq. co-2014?C130=1 (last access: 11 April 2018).

\section{The Supplement related to this article is available online at https://doi.org/10.5194/acp-18-8293-2018-supplement.}

Competing interests. The authors declare that they have no conflict of interest.

Acknowledgements. The authors thank UCR's machine-shop staff and NCAR's Research Aviation Facility's technicians for a smooth aircraft integration process and support throughout the project; Joshua Schwarz at NOAA ESRL for providing us the aircraft inlet system; Charles A. Brock at NOAA ESRL for lending us a condensation particle counter during the project; Ron Cohen and Carly Ebben at the University of California, Berkeley, for providing the alkyl nitrate data; Geoff Tyndall at NCAR for assistance with $\mathrm{NO}_{x}-\mathrm{O}_{3}$ measurements; the Colorado Department of Public Health and Environment for funding the project; and Hatch Project accession no. 233133 for data analysis support. CIRES affiliates were supported by NOAA award number NA17OAR4320101.

Edited by: Lynn M. Russell

Reviewed by: three anonymous referees

\section{References}

Abeleira, A., Pollack, I. B., Sive, B., Zhou, Y., Fischer, E. V., and Farmer, D. K.: Source characterization of volatile organic compounds in the Colorado Northern Front Range Metropolitan Area during spring and summer 2015, J. Geophys. Res.-Atmos., 122, 3595-3613, https://doi.org/10.1002/2016jd026227, 2017.

Adgate, J. L., Goldstein, B. D., and McKenzie, L. M.: Potential Public Health Hazards, Exposures and Health Effects from Unconventional Natural Gas Development, Environ. Sci. Technol., 48, 8307-8320, https://doi.org/10.1021/es404621d, 2014.

Ahmadov, R., McKeen, S., Trainer, M., Banta, R., Brewer, A., Brown, S., Edwards, P. M., de Gouw, J. A., Frost, G. J., Gilman, J., Helmig, D., Johnson, B., Karion, A., Koss, A., Langford, A., Lerner, B., Olson, J., Oltmans, S., Peischl, J., Pétron, G., Pichugina, Y., Roberts, J. M., Ryerson, T., Schnell, R., Senff, C., Sweeney, C., Thompson, C., Veres, P. R., Warneke, C., Wild, R.,
Williams, E. J., Yuan, B., and Zamora, R.: Understanding high wintertime ozone pollution events in an oil- and natural gasproducing region of the western US, Atmos. Chem. Phys., 15, 411-429, https://doi.org/10.5194/acp-15-411-2015, 2015.

Ahmadov, R., McKeen, S. A., Robinson, A. L., Bahreini, R., Middlebrook, A. M., de Gouw, J. A., Meagher, J., Hsie, E.-Y., Edgerton, E., Shaw, S., and Trainer, M.: A volatility basis set model for summertime secondary organic aerosols over the eastern United States in 2006, J. Geophys. Res.-Atmos., 117, D06301, https://doi.org/10.1029/2011JD016831, 2012.

Apel, E. C., Hornbrook, R. S., Hills, A. J., Blake, N. J., Barth, M. C., Weinheimer, A., Cantrell, C., Rutledge, S. A., Basarab, B., Crawford, J., Diskin, G., Homeyer, C. R., Campos, T., Flocke, F., Fried, A., Blake, D. R., Brune, W., Pollack, I., Peischl, J., Ryerson, T., Wennberg, P. O., Crounse, J. D., Wisthaler, A., Mikoviny, T., Huey, G., Heikes, B., O'Sullivan, D., and Riemer, D. D.: Upper tropospheric ozone production from lightning $\mathrm{NO}_{x}$-impacted convection: Smoke ingestion case study from the DC3 campaign, J. Geophys. Res.-Atmos., 120, 2505-2523, https://doi.org/10.1002/2014JD022121, 2015.

Bahreini, R., Dunlea, E. J., Matthew, B. M., Simons, C., Docherty, K. S., DeCarlo, P. F., Jimenez, J. L., Brock, C. A., and Middlebrook, A. M.: Design and Operation of a PressureControlled Inlet for Airborne Sampling with an Aerodynamic Aerosol Lens, Aerosol Sci. Technol., 42, 465-471, https://doi.org/10.1080/02786820802178514, 2008.

Bahreini, R., Ervens, B., Middlebrook, A. M., Warneke, C., de Gouw, J. A., DeCarlo, P. F., Jimenez, J. L., Atlas, E., Brioude, J., Brock, C. A., Fried, A., Holloway, J. S., Peischl, J., Richter, D., Ryerson, T. B., Stark, H., Walega, J., Weibring, P., Wollny, A. G., and Fehsenfeld, F. C.: Organic aerosol formation in urban and industrial plumes near Houston and Dallas, TX, J. Geophys. Res., 114, D00F16, https://doi.org/10.1029/2008JD011493, 2009.

Ban-Weiss, G. A., McLaughlin, J. P., Harley, R. A., Lunden, M. M., Kirchstetter, T. W., Kean, A. J., Strawa, A. W., Stevenson, E. D., and Kendall, G. R.: Long-term changes in emissions of nitrogen oxides and particulate matter from on-road gasoline and diesel vehicles, Atmos. Environ., 42, 220-232, https://doi.org/10.1016/j.atmosenv.2007.09.049, 2008.

Borbon, A., Gilman, J. B., Kuster, W. C., Grand, N., Chevaillier, S., Colomb, A., Dolgorouky, C., Gros, V., Lopez, M., Sarda-Esteve, R., Holloway, J., Stutz, J., Petetin, H., McKeen, S., Beekmann, M., Warneke, C., Parrish, D. D., and de Gouw, J. A.: Emission ratios of anthropogenic volatile organic compounds in northern mid-latitude megacities: Observations versus emission inventories in Los Angeles and Paris, J. Geophys. Res.-Atmos., 118, 2041-2057, https://doi.org/10.1002/jgrd.50059, 2013.

Encyclopaedia Britannica: Wet gas, available at: https://www. britannica.com/science/wet-gas (last access: 2018), 1998.

Canagaratna, M. R., Jayne, J. T., Jimenez, J. L., Allan, J. D., Alfarra, M. R., Zhang, Q., Onasch, T. B., Drewnick, F., Coe, H., Middlebrook, A. M., Delia, A., Williams, L. R., Trimborn, A. M., Northway, M. J., DeCarlo, P. F., Kolb, C. E., Davidovits, P., and Worsnop, D. R.: Chemical and Microphysical Characterization of Ambient Aerosols with the Aerodyne Aerosol Mass Spectrometer, Mass Spectrom. Rev., 26, 185-222, 2007.

Carter, W. P. L. and Seinfeld, J. H.: Winter ozone formation and VOC incremental reactivities in the Upper Green 
River Basin of Wyoming, Atmos. Environ., 50, 255-266, https://doi.org/10.1016/j.atmosenv.2011.12.025, 2012.

Colman, J. J., Swanson, A. L., Meinardi, S., Sive, B. C., Blake, D. R., and Rowland, F. S.: Description of the analysis of a wide range of volatile organic compounds in whole air samples collected during PEM-Tropics A and B, Anal. Chem., 73, 37233731, https://doi.org/10.1021/ac010027g, 2001.

Day, D. A., Wooldridge, P. J., Dillon, M. B., Thornton, J. A., and Cohen, R. C.: A thermal dissociation laser-induced fluorescence instrument for in situ detection of $\mathrm{NO}_{2}$, peroxy nitrates, alkyl nitrates, and $\mathrm{HNO}_{3}$, J. Geophys. Res.-Atmos., 107, 4046, 2002.

de Gouw, J. A., Brock, C. A., Atlas, E. L., Bates, T. S., Fehsenfeld, F. C., Goldan, P. D., Holloway, J. S., Kuster, W. C., Lerner, B. M., Matthew, B. M., Middlebrook, A. M., Onasch, T. B., Peltier, R. E., Quinn, P. K., Senff, C. J., Stohl, A., Sullivan, A. P., Trainer, M., Warneke, C., Weber, R. J., and Williams, E. J.: Sources of Particulate Matter in the Northeastern United States in Summer: 1. Direct Emissions and Secondary Formation of Organic Matter in Urban Plumes, J. Geophys. Res.-Atmos., 113, D08301, https://doi.org/10.1029/2007JD009243, 2008.

de Gouw, J. A., Middlebrook, A. M., Warneke, C., Ahmadov, R., Atlas, E. L., Bahreini, R., Blake, D. R., Brock, C. A., Brioude, J., Fahey, D. W., Fehsenfeld, F. C., Holloway, J. S., Henaff, M. L., Lueb, R. A., McKeen, S. A., Meagher, J. F., Murphy, D. M., Paris, C., Parrish, D. D., Perring, A. E., Pollack, I. B., Ravishankara, A. R., Robinson, A. L., Ryerson, T. B., Schwarz, J. P., Spackman, J. R., Srinivisan, A., and Watts, L. A.: Organic Aerosol Formation Downwind from the Deepwater Horizon Oil Spill, Science, 331, 1295-1299, https://doi.org/10.1126/science.1200320, 2011.

de Gouw, J. A. and Warneke, C.: Measurements of Volatile Organic Compounds in the Earth's Atmosphere Using Proton-TransferReaction Mass Spectrometry, Mass Spectrom. Rev., 26, 223 257, https://doi.org/10.1002/mas.20119, 2007.

Dingle, J. H., Vu, K., Bahreini, R., Apel, E. C., Campos, T. L., Flocke, F., Fried, A., Herndon, S., Hills, A. J., Hornbrook, R. S., Huey, G., Kaser, L., Montzka, D. D., Nowak, J. B., Reeves, M., Richter, D., Roscioli, J. R., Shertz, S., Stell, M., Tanner, D., Tyndall, G., Walega, J., Weibring, P., and Weinheimer, A.: Aerosol optical extinction during the Front Range Air Pollution and Photochemistry Éxperiment (FRAPPÉ) 2014 summertime field campaign, Colorado, USA, Atmos. Chem. Phys., 16, 11207-11217, https://doi.org/10.5194/acp-16-11207-2016, 2016.

Donahue, N. M. Robinson,, A. L., Stanier, C. O., and Pandis, S. N.: Coupled partitioning, dilution, and chemical aging of semivolatile organics, Environ. Sci. Technol., 40, 2635-2643, 2006.

Drewnick, F., Hings, S. S., DeCarlo, P., Jayne, J. T., Gonin, M., Fuhrer, K., Weimer, S., Jimenez, J. L., Borrmann, K. L. D. S., and Worsnop, D. R.: A new time-of-flight aerosol mass spectrometer (TOF-AMS) - Instrument description and first field deployment, Aerosol Sci. Technol., 39, 637-658, https://doi.org/10.1080/02786820500182040, 2005.

Edwards, P. M., Brown, S. S., Roberts, J. M., Ahmadov, R., Banta, R. M., deGouw, J. A., Dube, W. P., Field, R. A., Flynn, J. H., Gilman, J. B., Graus, M., Helmig, D., Koss, A., Langford, A. O., Lefer, B. L., Lerner, B. M., Li, R., Li, S. M., McKeen, S. A., Murphy, S. M., Parrish, D. D., Senff, C. J., Soltis, J., Stutz, J., Sweeney, C., Thompson, C. R., Trainer, M. K., Tsai, C., Veres,
P. R., Washenfelder, R. A., Warneke, C., Wild, R. J., Young, C. J., Yuan, B., and Zamora, R.: High winter ozone pollution from carbonyl photolysis in an oil and gas basin, Nature, 514, p. 351, https://doi.org/10.1038/nature13767, 2014.

Ehn, M., Thornton, J. A., Kleist, E., Sipila, M., Junninen, H., Pullinen, I., Springer, M., Rubach, F., Tillmann, R., Lee, B., Lopez-Hilfiker, F., Andres, S., Acir, I.-H., Rissanen, M., Jokinen, T., Schobesberger, S., Kangasluoma, J., Kontkanen, J., Nieminen, T., Kurten, T., Nielsen, L. B., Jorgensen, S., Kjaergaard, H. G., Canagaratna, M., Maso, M. D., Berndt, T., Petaja, T., Wahner, A., Kerminen, V.-M., Kulmala, M., Worsnop, D. R., Wildt, J., and Mentel, T. F.: A large source of lowvolatility secondary organic aerosol, Nature, 506, 476-479, https://doi.org/10.1038/nature13032, 2014.

Ensberg, J. J., Hayes, P. L., Jimenez, J. L., Gilman, J. B., Kuster, W. C., de Gouw, J. A., Holloway, J. S., Gordon, T. D., Jathar, S., Robinson, A. L., and Seinfeld, J. H.: Emission factor ratios, SOA mass yields, and the impact of vehicular emissions on SOA formation, Atmos. Chem. Phys., 14, 2383-2397, https://doi.org/10.5194/acp-14-2383-2014, 2014.

Ervens, B. and Volkamer, R.: Glyoxal processing by aerosol multiphase chemistry: towards a kinetic modeling framework of secondary organic aerosol formation in aqueous particles, Atmos. Chem. Phys., 10, 8219-8244, https://doi.org/10.5194/acp10-8219-2010, 2010.

Fast, J. D., Allan, J., Bahreini, R., Craven, J., Emmons, L., Ferrare, R., Hayes, P. L., Hodzic, A., Holloway, J., Hostetler, C., Jimenez, J. L., Jonsson, H., Liu, S., Liu, Y., Metcalf, A., Middlebrook, A., Nowak, J., Pekour, M., Perring, A., Russell, L., Sedlacek, A., Seinfeld, J., Setyan, A., Shilling, J., Shrivastava, M., Springston, S., Song, C., Subramanian, R., Taylor, J. W., Vinoj, V., Yang, Q., Zaveri, R. A., and Zhang, Q.: Modeling regional aerosol and aerosol precursor variability over California and its sensitivity to emissions and long-range transport during the $2010 \mathrm{CalNex}$ and CARES campaigns, Atmos. Chem. Phys., 14, 10013-10060, https://doi.org/10.5194/acp-14-10013-2014, 2014.

Field, R. A., Soltis, J., McCarthy, M. C., Murphy, S., and Montague, D. C.: Influence of oil and gas field operations on spatial and temporal distributions of atmospheric non-methane hydrocarbons and their effect on ozone formation in winter, Atmos. Chem. Phys., 15, 3527-3542, https://doi.org/10.5194/acp15-3527-2015, 2015.

Field, R. A., Soltis, J., and Murphy, S.: Air quality concerns of unconventional oil and natural gas production, Environ. Sci.-Process. Imp., 16, 954-969, https://doi.org/10.1039/c4em00081a, 2014.

Gerbig, C., Schmitgen, S., Kley, D., Volz-Thomas, A., Dewey, K., and Haaks, D.: An improved fast-response vacuum-UV resonance fluorescence CO instrument, J. Geophys. Res.-Atmos., 104, 1699-1704, 1999.

Gilman, J. B., Lerner, B. M., Kuster, W. C., and de Gouw, J. A.: Source Signature of Volatile Organic Compounds from Oil and Natural Gas Operations in Northeastern Colorado, Environ. Sci. Technol., 47, 1297-1305, https://doi.org/10.1021/es304119a, 2013.

Grell, G. A., Peckham, S. E., Schmitz, R., McKeen, S. A., Frost, G., Skamarock, W. C., and Eder, B.: Fully coupled "online" chemistry within the WRF model, Atmos. Environ., 39, 6957-6975, https://doi.org/10.1016/j.atmosenv.2005.04.027, 2005. 
Hallquist, M., Wenger, J. C., Baltensperger, U., Rudich, Y., Simpson, D., Claeys, M., Dommen, J., Donahue, N. M., George, C., Goldstein, A. H., Hamilton, J. F., Herrmann, H., Hoffmann, T., Iinuma, Y., Jang, M., Jenkin, M. E., Jimenez, J. L., Kiendler-Scharr, A., Maenhaut, W., McFiggans, G., Mentel, Th. F., Monod, A., Prévôt, A. S. H., Seinfeld, J. H., Surratt, J. D., Szmigielski, R., and Wildt, J.: The formation, properties and impact of secondary organic aerosol: current and emerging issues, Atmos. Chem. Phys., 9, 5155-5236, https://doi.org/10.5194/acp9-5155-2009, 2009.

Helmig, D., Rossabi, S., Hueber, J., Tans, P., Montzka, S. A., Masarie, K., Thoning, K., Plass-Duelmer, C., Claude, A., Carpenter, L. J., Lewis, A. C., Punjabi, S., Reimann, S., Vollmer, M. K., Steinbrecher, R., Hannigan, J., Emmons, L. K., Mahieu, E., Franco, B., Smale, D., and Pozzer, A.: Reversal of global atmospheric ethane and propane trends largely due to US oil and natural gas production, Nat. Geosci., 9, 490-495, https://doi.org/10.1038/ngeo2721, 2016.

Helmig, D., Thompson, C. R., Evans, J., Boylan, P., Hueber, J., and Park, J. H.: Highly Elevated Atmospheric Levels of Volatile Organic Compounds in the Uintah Basin, Utah, Environ. Sci. Technol., 48, 4707-4715, https://doi.org/10.1021/es405046r, 2014.

Hennigan, C. J., Miracolo, M. A., Engelhart, G. J., May, A. A., Presto, A. A., Lee, T., Sullivan, A. P., McMeeking, G. R., Coe, H., Wold, C. E., Hao, W.-M., Gilman, J. B., Kuster, W. C., de Gouw, J., Schichtel, B. A., Collett Jr., J. L., Kreidenweis, S. M., and Robinson, A. L.: Chemical and physical transformations of organic aerosol from the photo-oxidation of open biomass burning emissions in an environmental chamber, Atmos. Chem. Phys., 11, 7669-7686, https://doi.org/10.5194/acp11-7669-2011, 2011.

Hennigan, C. J., Sullivan, A. P., Collett, J. L., and Robinson, A. L.: Levoglucosan stability in biomass burning particles exposed to hydroxyl radicals, Geophys. Res. Lett., 37, L09806, https://doi.org/10.1029/2010g1043088, 2010.

Henze, D. K., Seinfeld, J. H., Ng, N. L., Kroll, J. H., Fu, T.-M., Jacob, D. J., and Heald, C. L.: Global modeling of secondary organic aerosol formation from aromatic hydrocarbons: highvs. low-yield pathways, Atmos. Chem. Phys., 8, 2405-2420, https://doi.org/10.5194/acp-8-2405-2008, 2008.

Hodzic, A. and Jimenez, J. L.: Modeling anthropogenically controlled secondary organic aerosols in a megacity: a simplified framework for global and climate models, Geosci. Model Dev., 4, 901-917, https://doi.org/10.5194/gmd-4-901-2011, 2011.

Hodzic, A., Jimenez, J. L., Madronich, S., Canagaratna, M. R., DeCarlo, P. F., Kleinman, L., and Fast, J.: Modeling organic aerosols in a megacity: potential contribution of semi-volatile and intermediate volatility primary organic compounds to secondary organic aerosol formation, Atmos. Chem. Phys., 10, 5491-5514, https://doi.org/10.5194/acp-10-5491-2010, 2010a.

Hodzic, A., Jimenez, J. L., Madronich, S., Canagaratna, M. R., DeCarlo, P. F., Kleinman, L., and Fast, J.: Modeling organic aerosols in a megacity: potential contribution of semi-volatile and intermediate volatility primary organic compounds to secondary organic aerosol formation, Atmos. Chem. Phys., 10, 5491-5514, https://doi.org/10.5194/acp-10-5491-2010, 2010b.

Hornbrook, R. S., Crawford, J. H., Edwards, G. D., Goyea, O., Mauldin III, R. L., Olson, J. S., and Cantrell, C. A.: Measurements of tropospheric $\mathrm{HO}_{2}$ and $\mathrm{RO}_{2}$ by oxygen dilution modulation and chemical ionization mass spectrometry, Atmos. Meas. Tech., 4, 735-756, https://doi.org/10.5194/amt-4735-2011, 2011.

Huey, L. G., Dunlea, E. J., Lovejoy, E. R., Hanson, D. R., Norton, R. B., Fehsenfeld, F. C., and Howard, C. J.: A chemical ionization mass spectrometer for fast time response measurements of HNO3 in air, J. Geophys. Res.-Atmos., 103, 3355-3360, 1998.

Isaacman, G., Wilson, K. R., Chan, A. W. H., Worton, D. R., Kimmel, J. R., Nah, T., Hohaus, T., Gonin, M., Kroll, J. H., Worsnop, D. R., and Goldstein, A. H.: Improved Resolution of Hydrocarbon Structures and Constitutional Isomers in Complex Mixtures Using Gas Chromatography-Vacuum Ultraviolet-Mass Spectrometry, Anal. Chem., 84, 2335-2342, https://doi.org/10.1021/ac2030464, 2012.

Jathar, S. H., Friedman, B., Galang, A. A., Link, M. F., Brophy, P., Volckens, J., Eluri, S., and Farmer, D. K.: Linking Load, Fuel, and Emission Controls to Photochemical Production of Secondary Organic Aerosol from a Diesel Engine, Environ. Sci. Technol., 51, 1377-1386, https://doi.org/10.1021/acs.est.6b04602, 2017.

Jayne, J. T., Leard, D. C., Zhang, X., Davidovits, P., Smith, K. A., Kolb, C. E., and Worsnop, D. W.: Development of an Aerosol Mass Spectrometer for size and composition analysis of submicron particles, Aerosol Sci. Technol., 33, 49-70, 2000.

Kirchstetter, T. W., Preble, C. V., Hadley, O. L., Bond, T. C., and Apte, J. S.: Large reductions in urban black carbon concentrations in the United States between 1965 and 2000, Atmos. Environ., 151, 17-23, https://doi.org/10.1016/j.atmosenv.2016.11.001, 2017.

Koss, A., Yuan, B., Warneke, C., Gilman, J. B., Lerner, B. M., Veres, P. R., Peischl, J., Eilerman, S., Wild, R., Brown, S. S., Thompson, C. R., Ryerson, T., Hanisco, T., Wolfe, G. M., Clair, J. M. St., Thayer, M., Keutsch, F. N., Murphy, S., and de Gouw, J.: Observations of VOC emissions and photochemical products over US oil- and gas-producing regions using high-resolution H3O+ CIMS (PTR-ToF-MS), Atmos. Meas. Tech., 10, 29412968, https://doi.org/10.5194/amt-10-2941-2017, 2017.

Koss, A. R., de Gouw, J., Warneke, C., Gilman, J. B., Lerner, B. M., Graus, M., Yuan, B., Edwards, P., Brown, S. S., Wild, R., Roberts, J. M., Bates, T. S., and Quinn, P. K.: Photochemical aging of volatile organic compounds associated with oil and natural gas extraction in the Uintah Basin, UT, during a wintertime ozone formation event, Atmos. Chem. Phys., 15, 5727-5741, https://doi.org/10.5194/acp-15-5727-2015, 2015.

Kroll, J. H., Ng, N. L., Murphy, S. M., Flagan, R. C., and Seinfeld, J. H.: Secondary organic aerosol formation from isoprene photooxidation under high- $\mathrm{NO}_{x}$ conditions, Geophys. Res. Lett., 32, L18808, https://doi.org/10.1029/2005GL023637, 2005.

Lim, Y. B. and Ziemann, P. J.: Products and mechanism of secondary organic aerosol formation from reactions of $n$-alkanes with $\mathrm{OH}$ radicals in the presence of $\mathrm{NO}_{x}$, Environ. Sci. Technol., 39, 9229-9236, https://doi.org/10.1021/es051447g, 2005.

Lindinger, W., Hansel, A., and Jordan, A.: On-line monitoring of volatile organic compounds at pptv levels by means of proton-transfer-reaction mass spectrometry (PTR-MS) medical applications, food control and environmental research, Int. J. Mass Spectrom., 173, 191-241, https://doi.org/10.1016/S01681176(97)00281-4, 1998. 
Lopez-Hilfiker, F. D., Mohr, C., Ehn, M., Rubach, F., Kleist, E., Wildt, J., Mentel, Th. F., Lutz, A., Hallquist, M., Worsnop, D., and Thornton, J. A.: A novel method for online analysis of gas and particle composition: description and evaluation of a Filter Inlet for Gases and AEROsols (FIGAERO), Atmos. Meas. Tech., 7, 983-1001, https://doi.org/10.5194/amt-7-983-2014, 2014.

Mauldin, R. L. I., Frost, G. J., Chen, G., Tanner, D. J., Prevot, A. S. H., Davis, D. D., and Eisele, F. L.: OH measurements during ACE-1: Observations and model comparisons, J. Geophys. Res., 103, 16713-16729, https://doi.org/10.1029/98JD00882, 1998.

May, A. A., Presto, A. A., Hennigan, C. J., Nguyen, N. T., Gordon, T. D., and Robinson, A. L.: Gas-Particle Partitioning of Primary Organic Aerosol Emissions: (2) Diesel Vehicles, Environ. Sci. Technol., 47, 8288-8296, https://doi.org/10.1021/es400782j, 2013

McDuffie, E. E., Edwards, P. M., Gilman, J. B., Lerner, B. M., Dube, W. P., Trainer, M., Wolfe, D. E., Angevine, W. M., deGouw, J., Williams, E. J., Tevlin, A. G., Murphy, J. G., Fischer, E. V., McKeen, S., Ryerson, T. B., Peischl, J., Holloway, J. S., Aikin, K., Langford, A. O., Senff, C. J., Alvarez, R. J., Hall, S. R., Ullmann, K., Lantz, K. O., and Brown, S. S.: Influence of oil and gas emissions on summertime ozone in the Colorado Northern Front Range, J. Geophys. Res.-Atmos., 121, 8712-8729, https://doi.org/10.1002/2016jd025265, 2016.

McLafferty, F. W. and Turecek, F.: Interpretation of Mass Spectra, Sausalito, CA, University Science Books, 1993.

Middlebrook, A. M., Bahreini, R., Jimenez, J. L., and Canagaratna, M. R.: Evaluation of composition-dependent collection efficiencies for the aerodyne aerosol mass spectrometer using field data, Aerosol Sci. Technol., 46, 258-271, 2012a.

Middlebrook, A. M., Murphy, D. M., Ahmadov, R., Atlas, E. L., Bahreini, R., Blake, D. R., Brioude, J., de Gouw, J. A., Fehsenfeld, F. C., Frost, G. J., Holloway, J. S., Lack, D. A., Langridge, J. M., Lueb, R. A., McKeen, S. A., Meagher, J. F., Meinardi, S., Neuman, J. A., Nowak, J. B., Parrish, D. D., Peischl, J., Perring, A. E., Pollack, I. B., Roberts, J. M., Ryerson, T. B., Schwarz, J. P., Spackman, J. R., Warneke, C., and Ravishankara, A. R.: Air quality implications of the Deepwater Horizon oil spill, P. Natl. Acad. Sci. USA, 109, 20280-20285, https://doi.org/10.1073/pnas.1110052108, 2012b.

Monks, P. S., Granier, C., Fuzzi, S., Stohl, A., Williams, M. L., Akimoto, H., Amann, M., Baklanov, A., Baltensperger, U., Bey, I., Blake, N., Blake, R. S., Carslaw, K., Cooper, O. R., Dentener, F., Fowler, D., Fragkou, E., Frost, G. J., Generoso, S., Ginoux, P., Grewe, V., Guenther, A., Hansson, H. C., Henne, S., Hjorth, J., Hofzumahaus, A., Huntrieser, H., Isaksen, I. S. A., Jenkin, M. E., Kaiser, J., Kanakidou, M., Klimont, Z., Kulmala, M., Laj, P., Lawrence, M. G., Lee, J. D., Liousse, C., Maione, M., McFiggans, G., Metzger, A., Mieville, A., Moussiopoulos, N., Orlando, J. J., O’Dowd, C. D., Palmer, P. I., Parrish, D. D., Petzold, A., Platt, U., Poschl, U., Prevot, A. S. H., Reeves, C. E., Reimann, S., Rudich, Y., Sellegri, K., Steinbrecher, R., Simpson, D., ten Brink, H., Theloke, J., van der Werf, G. R., Vautard, R., Vestreng, V., Vlachokostas, C., and von Glasow, R.: Atmospheric composition change - global and regional air quality, Atmos. Environ., 43, 5268-5350, https://doi.org/10.1016/j.atmosenv.2009.08.021, 2009.

NASA: National Aeronautics and Space Administration, Airborne Science Data for Atmospheric composition, available at: http://www-air.larc.nasa.gov/cgi-bin/ArcView/discover-aq. co-2014?C130=1, last access: 11 April 2018.

Ng, N. L., Canagaratna, M. R., Jimenez, J. L., Zhang, Q., Ulbrich, I. M., and Worsnop, D. R.: Real-time methods for estimating organic component mass concentrations from aerosol mass spectrometer data, Environ. Sci. Technol., 45, 910-916, https://doi.org/10.1021/es102951k, 2011.

Ng, N. L., Canagaratna, M. R., Zhang, Q., Jimenez, J. L., Tian, J., Ulbrich, I. M., Kroll, J. H., Docherty, K. S., Chhabra, P. S., Bahreini, R., Murphy, S. M., Seinfeld, J. H., Hildebrandt, L., Donahue, N. M., DeCarlo, P. F., Lanz, V. A., Prévôt, A. S. H., Dinar, E., Rudich, Y., and Worsnop, D. R.: Organic aerosol components observed in Northern Hemispheric datasets from Aerosol Mass Spectrometry, Atmos. Chem. Phys., 10, 46254641, https://doi.org/10.5194/acp-10-4625-2010, 2010.

Ng, N. L., Chhabra, P. S., Chan, A. W. H., Surratt, J. D., Kroll, J. H., Kwan, A. J., McCabe, D. C., Wennberg, P. O., Sorooshian, A., Murphy, S. M., Dalleska, N. F., Flagan, R. C., and Seinfeld, J. H.: Effect of $\mathrm{NO}_{x}$ level on secondary organic aerosol (SOA) formation from the photooxidation of terpenes, Atmos. Chem. Phys. 7, 5159-5174, https://doi.org/10.5194/acp-7-5159-2007, 2007a.

Ng, N. L., Kroll, J. H., Chan, A. W. H., Chhabra, P. S., Flagan, R. C., and Seinfeld, J. H.: Secondary organic aerosol formation from $m$-xylene, toluene, and benzene, Atmos. Chem. Phys., 7, 3909-3922, https://doi.org/10.5194/acp-7-3909-2007, 2007b.

Odum, J. R., Jungkamp, T. P. W., Griffin, R. J., Flagan, R. C., and Seinfeld, J. H.: The atmospheric aerosol-forming potential of whole gasoline vapor, Science, 276, 96-99, https://doi.org/10.1126/science.276.5309.96, 1997a.

Odum, J. R., Jungkamp, T. P. W., Griffin, R. J., Forstner, H. J. L., Flagan, R. C., and Seinfeld, J. H.: Aromatics, reformulated gasoline, and atmospheric organic aerosol formation, Environ. Sci. Technol., 31, 1890-1897, 1997b.

Paatero, P.: A weighted non-negative least squares algorithm for three-way 'PARAFAC' factor analysis, Chemometr Intell Lab, 38, 223-242, 1997.

Paatero, P. and Tapper, U.: Positive Matrix Factorization - a Nonnegative Factor Model with Optimal Utilization of ErrorEstimates of Data Values, Environmetrics, 5, 111-112, 1994

Parrish, D. D., Trainer, M., Hereid, D., Williams, E. J., Olszyna, K. J., Harley, R. A., Meagher, J. F., and Fehsenfeld, F. C.: Decadal change in carbon monoxide to nitrogen oxide ratio in US vehicular emissions, J. Geophys. Res.-Atmos., 107, D12, https://doi.org/10.1029/2001JD000720, 2002.

Peischl, J., Ryerson T. B., Holloway, J. S., Parrish, D. D., Trainer, M., Frost, G. J., Aikin, K. C., Brown, S. S., Dube, W. P., Stark, H., and Fehsenfeld, F. C.: A top-down analysis of emissions from selected Texas power plants during TexAQS 2000 and 2006, J. Geophys. Res.-Atmos., 115, D16303, https://doi.org/10.1029/2009jd013527, 2010.

Pekney, N. J., Veloski, G., Reeder, M., Tamilia, J., Rupp, E., and Wetzel, A.: Measurement of atmospheric pollutants associated with oil and natural gas exploration and production activity in Pennsylvania's Allegheny National Forest, J. Air Waste Manage. Assoc., 64, 1062-1072, https://doi.org/10.1080/10962247.2014.897270, 2014.

Petron, G., Frost, G., Miller, B. R., Hirsch, A. I., Montzka, S. A., Karion, A., Trainer, M., Sweeney, C., Andrews, A. E., Miller, L., Kofler, J., Bar-Ilan, A., Dlugokencky, E. J., Patrick, L., 
Moore, C. T., Ryerson, T. B., Siso, C., Kolodzey, W., Lang, P. M., Conway, T., Novelli, P., Masarie, K., Hall, B., Guenther, D., Kitzis, D., Miller, J., Welsh, D., Wolfe, D., Neff, W., and Tans, P.: Hydrocarbon emissions characterization in the Colorado Front Range: A pilot study, J. Geophys. Res., 117, D04304, https://doi.org/10.1029/2011jd016360, 2012.

Petron, G., Karion, A., Sweeney, C., Miller, B. R., Montzka, S. A., Frost, G. J., Trainer, M., Tans, P., Andrews, A., Kofler, J., Helmig, D., Guenther, D., Dlugokencky, E., Lang, P., Newberger, T., Wolter, S., Hall, B., Novelli, P., Brewer, A., Conley, S., Hardesty, M., Banta, R., White, A., Noone, D., Wolfe, D., and Schnell, R.: A new look at methane and nonmethane hydrocarbon emissions from oil and natural gas operations in the Colorado Denver-Julesburg Basin, J. Geophys. Res.-Atmos., 119, 6836-6852, https://doi.org/10.1002/2013jd021272, 2014.

Pfister, G., Flocke, F., Hornbrook, R., Orlando, J., Lee, S., and Schroeder, J.: Process-Based and Regional Source Impact Analysis for FRAPPÉ and DISCOVER - AQ 2014, available at: https://www.colorado.gov/airquality/tech_doc_repository.aspx? action=open\&file=FRAPPE-NCAR_Final_Report_July2017. pdf, last access: 5 December 2017.

Powers, J. G., Klemp, J. B., Skamarock, W. C., Davis, C. A., Dudhia, J., Gill, D. O., Coen, J. L., Gochis, D. J., Ahmadov, R., Peckham, S. E., Grell, G. A., Michalakes, J., Trahan, S., Benjamin, S. G., Alexander, C. R., Dimego, G. J., Wang, W., Schwartz, C. S., Romine, G. S., Liu, Z. Q., Snyder, C., Chen, F., Barlage, M. J., Yu, W., and Duda, M. G.: THE WEATHER RESEARCH AND FORECASTING MODEL Overview, System Efforts, and Future Directions, B. Am. Meteorol. Soc., 8, 17171737, https://doi.org/10.1175/bams-d-15-00308.1, 2017.

Prenni, A. J., Day, D. E., Evanoski-Cole, A. R., Sive, B. C., Hecobian, A., Zhou, Y., Gebhart, K. A., Hand, J. L., Sullivan, A. P., Li, Y., Schurman, M. I., Desyaterik, Y., Malm, W. C., Collett Jr., J. L., and Schichtel, B. A.: Oil and gas impacts on air quality in federal lands in the Bakken region: an overview of the Bakken Air Quality Study and first results, Atmos. Chem. Phys., 16, 14011416, https://doi.org/10.5194/acp-16-1401-2016, 2016.

Rappenglück, B., Ackermann, L., Alvarez, S., Golovko, J., Buhr, M., Field, R. A., Soltis, J., Montague, D. C., Hauze, B., Adamson, S., Risch, D., Wilkerson, G., Bush, D., Stoeckenius, T., and Keslar, C.: Strong wintertime ozone events in the Upper Green River basin, Wyoming, Atmos. Chem. Phys., 14, 4909-4934, https://doi.org/10.5194/acp-14-4909-2014, 2014.

Ren, X., Mao, J., Brune, W. H., Cantrell, C. A., Mauldin III, R. L., Hornbrook, R. S., Kosciuch, E., Olson, J. R., Crawford, J. H., Chen, G., and Singh, H. B.: Airborne intercomparison of HOx measurements using laser-induced fluorescence and chemical ionization mass spectrometry during ARCTAS, Atmos. Meas. Tech., 5, 2025-2037, https://doi.org/10.5194/amt-5-2025-2012, 2012.

Richter, D., Weibring, P., Walega, J., Fried, A., Spuler, S. M., and Taubmans, M. S.: Compact highly sensitive multispecies airborne mid-IR spectrometer, Appl. Phys. B, 119, https://doi.org/10.1007/s00340-015-6038-8, 2015.

Ridley, B., Ott, L., Pickering, K., Emmons, L., Montzka. D., Weinheimer. A., Knapp. D., Grahek. F., Li. L., Heymsfield. G., McGill. M., Kucera. P., Mahoney. M. J., Baumgardner, D., Schultz, M., and Brasseur, G.: Florida thunderstorms: A faucet of reactive nitrogen to the upper troposphere, J. Geophys. Res.-
Atmos., 109, D17305, https://doi.org/10.1029/2004JD004769, 2004.

Rocky Mountain Energy Forum: Wattenberg Field, available at: http://www.rockymountainenergyforum.com/topics/ wattenberg-field, last access: 20 June 2015.

Rutter, A. P., Griffin, R. J., Cevik, B. K., Shakya, K. M., Gong, L. W., Kim, S., Flynn, J. H., and Lefer, B. L.: Sources of air pollution in a region of oil and gas exploration downwind of a large city, Atmos. Environ., 120, 89-99, https://doi.org/10.1016/j.atmosenv.2015.08.073, 2015.

Sather, M. E. and Cavender, K.: Update of long-term trends analysis of ambient 8-hour ozone and precursor monitoring data in the South Central U.S.; encouraging news, J. Environ. Monit., 14, 666-676, https://doi.org/10.1039/c2em10862c, 2012.

Shrivastava, M., Fast, J., Easter, R., Gustafson Jr., W. I., Zaveri, R. A., Jimenez, J. L., Saide, P., and Hodzic, A.: Modeling organic aerosols in a megacity: comparison of simple and complex representations of the volatility basis set approach, Atmos. Chem. Phys., 11, 6639-6662, https://doi.org/10.5194/acp11-6639-2011, 2011.

Sullivan, J. T., McGee, T. J., Langford, A. O., Alvarez II, R. J., Senff, C. J., Reddy, P. J., Thompson, A. M., Twigg, L. W., Sumnicht, G. K., Lee, P., Weinheimer, A., Knote, C., Long, R. W., and Hoff, R. M.: Quantifying the contributio of thermally drivern recirculation to a high-ozone event along the Colorado Front Range using lidar, J. Geophys. Res.-Atmos., 121, 10377-10390, https://doi.org/10.1002/2016JD025229, 2016.

Swarthout, R. F., Russo, R. S., Zhou, Y., Hart, A. H., and Sive, B. C.: "Volatile organic compound distributions during the NACHTT campaign at the Boulder Atmospheric Observatory: Influence of urban and natural gas sources, J. Geophys. Res.-Atmos., 118, 10614-10637, https://doi.org/10.1002/jgrd.50722, 2013.

Swarthout, R. F., Russo, R. S., Zhou, Y., Miller, B. M., Mitchell, B., Horsman, E., Lipsky, E., McCabe, D. C., Baum, E., and Sive, B. C.: Impact of Marcellus Shale Natural Gas Development in Southwest Pennsylvania on Volatile Organic Compound Emissions and Regional Air Quality, Environ. Sci. Technol., 49, 3175 3184, https://doi.org/10.1021/es504315f, 2015.

Tsimpidi, A. P., Karydis, V. A., Zavala, M., Lei, W., Molina, L., Ulbrich, I. M., Jimenez, J. L., and Pandis, S. N.: Evaluation of the volatility basis-set approach for the simulation of organic aerosol formation in the Mexico City metropolitan area, Atmos. Chem. Phys., 10, 525-546, https://doi.org/10.5194/acp-10-5252010, 2010.

Ulbrich, I. M., Canagaratna, M. R., Zhang, Q., Worsnop, D. R., and Jimenez, J. L.: Interpretation of organic components from Positive Matrix Factorization of aerosol mass spectrometric data, Atmos. Chem. Phys., 9, 2891-2918, https://doi.org/10.5194/acp-92891-2009, 2009.

USEDC (U.S. Energy Development Corporation): Natural gas: dry vs. wet, available at: http://www.usenergydevcorp.com/media_ downloads/Natural\%20Gas\%20Dry\%20Vs\%20Wet_050913. pdf, last access: 20 June 2015

Vu, K. T., Dingle, J. H., Bahreini, R., Reddy, P. J., Apel, E. C., Campos, T. L., DiGangi, J. P., Diskin, G. S., Fried, A., Herndon, S. C., Hills, A. J., Hornbrook, R. S., Huey, G., Kaser, L., Montzka, D. D., Nowak, J. B., Pusede, S. E., Richter, D., Roscioli, J. R., Sachse, G. W., Shertz, S., Stell, M., Tanner, D., Tyndall, G. S., Walega, J., Weibring, P., Weinheimer, A. J., Pfister, 
G., and Flocke, F.: Impacts of the Denver Cyclone on regional air quality and aerosol formation in the Colorado Front Range during FRAPPÉ 2014, Atmos. Chem. Phys., 16, 12039-12058, https://doi.org/10.5194/acp-16-12039-2016, 2016.

Warneke, C., de Gouw, J. A., Edwards, P. M., Holloway, J. S., Gilman, J. B., Kuster, W. C., Graus, M., Atlas, E., Blake, D., Gentner, D. R., Goldstein, A. H., Harley, R. A., Alvarez, S., Rappenglueck, B., Trainer, M., and Parrish, D. D.: Photochemical aging of volatile organic compounds in the Los Angeles basin: Weekday-weekend effect, J. Geophys. Res.-Atmos., 118, 50185028, https://doi.org/10.1002/jgrd.50423, 2013.

Warneke, C., deGouw, J. A., Holloway, J. S., Peischl, J., Ryerson, T. B., Atlas, E., Blake, D., Trainer, M., and Parrish, D. D.: Multiyear trends in volatile organic compounds in Los Angeles, California: Five decades of decreasing emissions, J. Geophys. Res., 117, D00V17, https://doi.org/10.1029/2012JD017899, 2012.

Warneke, C., Geiger, F., Edwards, P. M., Dube, W., Pétron, G., Kofler, J., Zahn, A., Brown, S. S., Graus, M., Gilman, J. B., Lerner, B. M., Peischl, J., Ryerson, T. B., de Gouw, J. A., and Roberts, J. M.: Volatile organic compound emissions from the oil and natural gas industry in the Uintah Basin, Utah: oil and gas well pad emissions compared to ambient air composition, Atmos. Chem. Phys., 14, 10977-10988, https://doi.org/10.5194/acp-1410977-2014, 2014.

Warneke, C., McKeen, S. A., deGouw, J. A., Goldan, P. D., Kuster, W. C., Holloway, J. S., Williams, E. J., Lerner, B. M., Parrish, D. D., Trainer, M., Fehsenfeld, F. C., Kato, S., Atlas, E. L., Baker, A., and Blake, D. R.: Determination of urban volatile organic compound emission ratios and comparison with an emissions database, J. Geophys. Res.-Atmos., 112, D10S47, https://doi.org/10.1029/2006JD007930, 2007.

Williams, B. J., Jayne, J. T., Lambe, A. T., Hohaus, T., Kimmel, J. R., Sueper, D., Brooks, W., Williams, L. R., Trimborn, A. M., Martinez, R. E., Hayes, P. L., Jimenez, J. L., Kreisberg, N. M., Hering, S. V., Worton, D. R., Goldstein, A. H., and Worsnop, D. R.: The First Combined Thermal Desorption Aerosol Gas Chromatograph-Aerosol Mass Spectrometer (TAG-AMS), Aerosol Sci. Technol., 48, 358-370, https://doi.org/10.1080/02786826.2013.875114, 2014.
Yatavelli, R. L. N., Lopez-Hilfiker, F., Wargo, J. D., Kimmel, J. R., Cubison, M. J., Bertram, T. H., Jimenez, J. L., Gonin, M., Worsnop, D. R., and Thornton, J. A.: A Chemical Ionization High-Resolution Time-of-Flight Mass Spectrometer Coupled to a Micro Orifice Volatilization Impactor (MOVI-HRToF-CIMS) for Analysis of Gas and ParticlePhase Organic Species, Aerosol Sci. Technol., 46, 1313-1327, https://doi.org/10.1080/02786826.2012.712236, 2012.

Zhang, Q., Jimenez, J. L., Canagaratna, M. R., Allan, J. D., Coe, H., Ulbrich, I., Alfarra, M. R., Takami, A., Middlebrook, A. M., Sun, Y. L., Dzepina, K., Dunlea, E., Docherty, K., DeCarlo, P. F., Salcedo, D., Onasch, T., Jayne, J. T., Miyoshi, T., Shimono, A., Hatakeyama, S., Takegawa, N., Kondo, Y., Schneider, J., Drewnick, F., Borrmann, S., Weimer, S., Demerjian, K., Williams, P., Bower, K., Bahreini, R., Cottrell, L., Griffin, R. J., Rautiainen, J., Sun, J. Y., Zhang, Y. M., and Worsnop, D. R.: Ubiquity and dominance of oxygenated species in organic aerosols in anthropogenically-influenced Northern Hemisphere midlatitudes, Geophys. Res. Lett., 34, L13801, https://doi.org/10.1029/2007GL029979, 2007.

Zhang, Q., Jimenez, J. L., Canagaratna, M. R., Ulbrich, I. M., Ng, N. L., Worsnop, D. R., and Sun, Y.: Understanding atmospheric organic aerosols via factor analysis of aerosol mass spectrometry: a review, Anal. Bioanal. Chem., 401, 3045-3067, https://doi.org/10.1007/s00216-11-5355-y, 2011.

Zheng, W., Flocke, F. M., Tyndall, G. S., Swanson, A., Orlando, J. J., Roberts, J. M., Huey, L. G., and Tanner, D. J.: Characterization of a thermal decomposition chemical ionization mass spectrometer for the measurement of peroxy acyl nitrates (PANs) in the atmosphere, Atmos. Chem. Phys., 11, 6529-6547, https://doi.org/10.5194/acp-11-6529-2011, 2011.

Zhou, W., Cohan, D. S., and Henderson, B. H.: Slower ozone production in Houston, Texas following emission reductions: evidence from Texas Air Quality Studies in 2000 and 2006, Atmos. Chem. Phys., 14, 2777-2788, https://doi.org/10.5194/acp14-2777-2014, 2014. 